IZA DP No. 819

\title{
Brain Drain and LDCs' Growth:
} Winners and Losers

Michel Beine

Frédéric Docquier

Hillel Rapoport

July 2003 


\title{
Brain Drain and LDCs' Growth: Winners and Losers
}

\author{
Michel Beine \\ University of Lille II, \\ Free University of Brussels \\ Frédéric Docquier \\ University of Lille II and IZA Bonn \\ Hillel Rapoport \\ University of Lille II, Bar-Ilan University, \\ Stanford University
}

\author{
Discussion Paper No. 819 \\ July 2003
}

\author{
IZA \\ P.O. Box 7240 \\ D-53072 Bonn \\ Germany \\ Tel.: +49-228-3894-0 \\ Fax: +49-228-3894-210 \\ Email: iza@iza.org
}

\begin{abstract}
This Discussion Paper is issued within the framework of IZA's research area Mobility and Flexibility of Labor. Any opinions expressed here are those of the author(s) and not those of the institute. Research disseminated by IZA may include views on policy, but the institute itself takes no institutional policy positions.

The Institute for the Study of Labor (IZA) in Bonn is a local and virtual international research center and a place of communication between science, politics and business. IZA is an independent, nonprofit limited liability company (Gesellschaft mit beschränkter Haftung) supported by Deutsche Post World Net. The center is associated with the University of Bonn and offers a stimulating research environment through its research networks, research support, and visitors and doctoral programs. IZA engages in (i) original and internationally competitive research in all fields of labor economics, (ii) development of policy concepts, and (iii) dissemination of research results and concepts to the interested public. The current research program deals with (1) mobility and flexibility of labor, (2) internationalization of labor markets, (3) welfare state and labor market, (4) labor markets in transition countries, (5) the future of labor, (6) evaluation of labor market policies and projects and (7) general labor economics.
\end{abstract}

IZA Discussion Papers often represent preliminary work and are circulated to encourage discussion. Citation of such a paper should account for its provisional character. A revised version may be available on the IZA website (www.iza.org) or directly from the author. 


\section{ABSTRACT \\ Brain Drain and LDCs' Growth: Winners and Losers*}

We present an empirical evaluation of the growth effects of the brain drain for the source countries of migrants. Using recent US data on migration rates by education levels (Carrington and Detragiache, 1998), we find empirical support for the "beneficial brain drain hypothesis" in a cross-section of 50 developing countries. At the country-level, we find that most countries combining low levels of human capital and low migration rates of skilled workers tend to be positively affected by the brain drain. By contrast, the brain drain appears to have negative growth effects in countries where the migration rate of the highly educated is above $20 \%$ and/or where the proportion of people with higher education is above $5 \%$. While the number of winners is smaller, these include nearly $80 \%$ of the total population of the sample.

JEL Classification: F22, J24, O15

Keywords: $\quad$ brain drain, migration, growth, human capital formation, immigration policy

Corresponding author:

Frédéric Docquier

CADRE

University of Lille II

1 Place Déliot

59084 Lille

France

Email: f.docquier@skynet.be

\footnotetext{
* This paper received the Milken Institute Award for distinguished economic research (Los Angeles, March 2003). We thank participants at the European Economic Association Meeting (Lausanne, September 2001), the Applied Econometrics Association Congress (Meknes, September 2001), the workshop of the French Commissariat du Plan (Paris, September 2001), and seminar audiences at DELTA, Stanford University, University of Lille, Ottawa University, and University of Liege, for useful comments. The paper benefited from invaluable remarks from Andrea Bassanini, François Bourguignon, Serge Coulombe, David McKenzie, Hubert Jayet, Abdul Noury, Sergio Perelman, Pierre Pestieau, Thomas Piketti, and Jacques Silber. The usual disclaimer applies.
} 


\section{Brain drain and LDCs' growth: winners and losers ${ }^{1}$}

\section{Introduction}

The term "brain drain" designates the international transfer of resources in the form of human capital, i.e., the migration of relatively highly educated individuals from developing to developed countries. ${ }^{2}$ This issue has undergone extensive scrutiny since the 1960s (Grubel and Scott, 1966, Johnson, 1967), with this early literature concluding that the welfare of those left behind would fall if the migrants' contribution to the economy were greater than their marginal product. Since this would seem to be the case when the social return to education exceeds its private return, and given the fact that education is often at least partly publicly financed, it was widely recognized until recently that the brain drain was detrimental to the migrants' source countries. Typical of this view is the following citation from a classical textbook in development economics: "the irony of international migration today is that ... many of the people who migrate legally from poor to richer lands are the very ones that Third World countries can least afford to lose: the highly educated and skilled. Since the great majority of these migrants move on a permanent basis, this perverse brain drain not only represents a loss of valuable human resources but could prove to be a serious constraint on the future economic progress of Third World nations" (Todaro, 1996: 119). In the same vein, a major contributor to the brain drain economic literature of the 1970s argued that "in contrast to the case of foreign investment, where the gain from the international factor movement is divided by the two countries, the developed country gains now at the cost of those left behind in the less-developed country. The emigrants similarly are seen to gain at the sacrifice of those left behind" (Hamada, 1977, p. 20). In other words, the international mobility of skilled workers was seen

\footnotetext{
${ }^{1}$ This paper received the Milken Institute Award for distinguished economic research (Los Angeles, March 2003). We thank participants at the European Economic Association Meeting (Lausanne, September 2001), the Applied Econometrics Association Congress (Meknes, September 2001), the workshop of the French Commissariat du Plan (Paris, September 2001), and seminar audiences at DELTA, Stanford University, University of Lille, Ottawa University, and University of Liege, for useful comments. The paper benefited from invaluable remarks from Andrea Bassanini, François Bourguignon, Serge Coulombe, David McKenzie, Hubert Jayet, Abdul Noury, Sergio Perelman, Pierre Pestieau, Thomas Piketti, and Jacques Silber. The usual disclaimer applies.

${ }^{2}$ In the non-academic literature, the term may be used in a narrower sense, and relates more specifically to the migration of engineers, physicians, scientists or other very highly skilled professionals with university training.
} 
as a zero-sum game, and most policy debates in the 1970s concentrated on whether a "tax on brains" (later coined "Bhagwati tax") could compensate the sending countries for the losses incurred as a result of the brain drain. ${ }^{3}$ The current debate on the brain drain, however, rests on new arguments, and on a new reality.

At the empirical level, there is a fair amount of evidence suggesting that the brain drain is now much more extensive than, say, 25 years ago. While only 300,000 highly skilled workers emigrated from all developing countries to the Western Nations in the period 1961-72 (UNCTAD, 1975), the US 1990 Census revealed that there were more than two and a half million highly educated immigrants from developing countries residing in the United States. This increased brain drain is also apparent from regional and national figures. The relative cumulative "loss of brains" by region in 1990 has been estimated at 15\% for Central America, 6\% for Africa, 3\% for South America, and 5\% for Asia (Carrington and Detragiache, 1998), with the latter region providing by far the largest fraction of the total. For Africa, Haque and Jahangir (1999) indicate that the number of highly skilled emigrants increased from 1,800 a year in average in 1960-75 to 4,400 in 1975-84 and 23,000 in 1984-87. Although policy debates in the US and other Western countries tend to focus on low-skill illegal immigration from the periphery, such migration patterns are not the whole picture. For example, Asian immigrants to the US, Canada and Australia in the 1980s were typically better educated on average than the native population, and also than immigrants from developed countries such as the United Kingdom (Ong et al., 1992). ${ }^{4}$ Country studies recently commissioned by the International Labor Organization reveal that $40 \%$ of Philippines' emigrants are college educated, that $12 \%$ of Uruguay's professionals and technicians live abroad, and, more surprisingly, that Mexico in 1990 was also the world's third largest exporter of tertiary educated migrants (Lowell and Findlay, 2001).

These trends are likely to have been confirmed in the 1990s in the face of the increasingly "quality-selective" immigration policies introduced in many OECD countries. Since 1984, Australia's immigration policy had officially privileged skilled work-

\footnotetext{
${ }^{3}$ See the special issue of the Journal of Public Economics edited by Jagdish Bhagwati on "Income taxation in the presence of international personal mobility", August 1982, and Bhagwati and Hamada (1974).

${ }^{4}$ Casual evidence suggests that this is indeed the case; for example, Saxenian (1999) estimates that immigrants accounted for 32 percent of the Silicon Valley's scientific and engineering workforce in 1990, the majority of whom originated from China and India (51 and 23 percent respectively).
} 
ers, with the candidates selected according to their prospective "contribution to the Australian economy". Canadian immigration policy follows along similar lines, resulting in an increasing share of highly educated people among the immigrants selected; for example, in 1997, 50,000 professional specialists and entrepreneurs immigrated to Canada with 75,000 additional family members, representing $58 \%$ of total immigration. In the US, since the Immigration Act of 1990 - followed by the American Competitiveness and Work Force Improvement Act of 1998 -, emphasis has been put on the selection of highly skilled workers through a system of quotas favoring candidates with academic degrees and/or specific professional skills. For that latter category, the annual number of visas issued for highly skilled professionals $(\mathrm{H}-1 \mathrm{~B}$ visas) increased from 48,000 in 1989 to 116,000 in 1999, the totality of this increase being due to immigration from developing countries, especially India (Lowell, 2000). In the EU countries, immigration policies are less clear and still oriented towards traditional targets such as asylum seekers and applicants requesting family reunion. However, there is some evidence suggesting that European countries are also leaning towards becoming quality-selective. For example, in Germany, Chancelor Schröder announced in May 2000 plans to recruit 10,000 additional specialists in the field of information technology. In France, the Weil Report on Immigration of 1997 also explicitly recommended favoring the immigration of highly educated workers. ${ }^{5}$

The institutional background of the brain drain, therefore, is now characterized by a "demand pull" on the side of the receiving countries, whose immigration policies are determined according to domestic needs and labor-market conditions, regardless of the consequences for the immigrants' origin countries. Combined with traditional self-selection effects on the supply side, this leads to much higher migration rates among the highly educated, and increased international transfers of human capital from developing to developed countries. In other words, human capital is flowing to where it is already abundant (Easterly and Levine, 2001).

What are the consequences for developing countries? Strangely enough, there has been no systematic empirical assessment of the economic impact of the brain drain for developing countries. The main reason for this seems to be the lack of harmonized international data on migration flows by origin country and education level. ${ }^{6}$ In

\footnotetext{
${ }^{5}$ Most figures are from OECD (2000).

${ }^{6}$ Even without considering the skill composition of migration flows, there are many difficulties inherent to the collection of international migration data. Among these, Zlotnik (1998, p. 429) notably mentions the fact that many countries "either lack a system for the continuous registration
} 
the absence of such empirical material, the debate has remained almost exclusively theoretical, with the following arguments put forward. First, alongside refinements around the "externality" argument (e.g., Usher, 1977, Blomqvist, 1986), the negative effects of the brain drain for source countries have been reformulated in an endogenous growth framework (Miyagiwa, 1991, Haque and Kim, 1995, Reichlin and Rustichini, 1998, Wong and Yip, 1999). Second, the effects of migration prospects on human capital formation have been the focus of several recent studies (Mountford, 1997, Stark et al., 1998, Vidal, 1998, Beine et al., 2001), suggesting that such prospects may in fact foster human capital formation and growth at origin. ${ }^{7}$ The essence of the argument is that if the return to education is higher abroad than at home, the possibility of migration increases the expected return to human capital, thereby enhancing domestic enrollment in education. More people, therefore, invest in human capital as a result of increased migration opportunities. Since only some of them actually emigrate, there may be an overall increase in the country's post-migration level of human capital. ${ }^{8}$ Alongside the incentives to acquire education, other channels whereby the brain drain may positively affect the sending economy have also been proposed. These include a range of "feedback effects" such as remittances, return migration after additional knowledge and skills have been acquired abroad, and the creation of business and trade networks. ${ }^{9}$

As mentioned above, the literature on migration and human capital formation is almost exclusively theoretical. To the best of our knowledge, the only empirical

of international migration or, if they have such a system, do not process and publish the data emanating from it", and that "among those countries that do produce statistics on international migration, the meaning and scope of those statistics vary considerably".

${ }^{7}$ Most of these papers use an OLG framework in the spirit of Galor and Tsiddon (1997). Using a slightly different perspective, Stark et al. (1997) elaborate on the possibility of a brain gain associated with a brain drain in a context of imperfect information with return migration. McCormick and Wahba (2000) also obtain the result that more highly-skilled migration may benefit to those left behind, but in a trade-theoretic model where migration, remittances and domestic labor-market outcomes are jointly determined and multiple equilibria arise, with the high-migration equilibrium pareto-dominating the low-migration equilibrium.

${ }^{8}$ The idea that education investments are impacted by migration prospects is not new and may be traced back in the brain drain literature at least to McCullock and Yellen (1977). The novelty lies in the introduction of uncertainty into the migration process, which creates the possibility of a net gain for the source country.

${ }^{9}$ See Rapoport and Docquier (2003) for a survey on the growth effects of remittances, and Domingues Dos Santos and Postel-Vinay (2003) on return migration and knowledge diffusion. A "diaspora externality" has long been recognized in the sociological literature (Gaillard and Gaillard, 1997, and Lowell and Findlay, 2001, review this literature) and, more recently, in the field of international trade (e.g., Gould, 1994, Rauch and Trindade, 2002). 
study at an aggregate level is that of Beine et al. (2001), who found a positive and significant effect of migration prospects on human capital formation in a cross-section of 37 developing countries. However, their study suffers from poor quality data. In particular, they used gross migration rates as a proxy measure for the brain drain due to the lack of available data on migration rates by education levels. This void was recently filled by Carrington and Detragiache (henceforth CD), who computed emigration rates at three educational levels (primary, secondary and tertiary) for a large set of developing countries and emphasized the overall tendency for migration rates to be much higher for the highly educated. The CD indicators constitute the only comparative data available on the brain drain; however, they suffer from several limitations: (i) They concern stocks of migrants rather than flows; (ii) They are available only for one year, 1990; and, (iii) They are constructed on the basis of various assumptions which appear to be very strong for some countries. In spite of these limitations, their estimations of emigration rates by educational levels are highly reliable for a relatively large number of LDCs, as we explain in Section 3.

The first objective of this research is to contribute to the empirical analysis of the brain drain at the aggregate level through the use of the CD data. Using their estimates for the upper level in a sample of 50 developing countries, we find a positive and significant effect of migration on human capital formation. This is in line with previous results (Beine et al., 2001), but based on much better data. The second objective of this research is to distinguish between countries for which the overall effect of the brain drain is positive and countries which are impoverished by the brain drain, as would be expected in the traditional view. Again, this issue has not been addressed previously in a systematic way. For each country of the sample, we sign the effect of a marginal increase in the migration rate of the highly educated, and estimate its growth performance would this migration rate be set to zero. This allows us to distinguish between winners and losers among source countries, and to derive country-specific policy implications. We find that while there are more losers than winners, the latter include the most important countries in term of demographic size.

The remainder of this paper is organized as follows. Section 2 presents the theoretical background and derives the main testable implications of the analysis. Section 3 details the procedure used by Carrington and Detragiache to obtain their estimates, points out possible limitations, and recommends to perform the analysis using sub-samples for which the data quality is most reliable. The empirical analysis is pre- 
sented in Section 4; we first address a number of specification issues, and then give the results for the full sample. Section 5 is dedicated to country-specific calculations; these allow to distinguish between winning and losing countries and compare such gains and losses in terms of annual GDP growth. Section 6 consists of a robustness analysis: the results are shown to be robust with respect to the use of sub-samples differentiated by their data quality; in addition, this section also tests for possible non-linearities in the relationship between migration and growth, as suggested by previous research. Section 7 concludes.

\section{The model}

In this section we summarize the basic mechanisms at work in the above cited literature on migration prospects and growth, and then detail the empirical model.

\subsection{Theoretical background}

Consider a small open developing economy taking the world interest rate as given, where all markets are competitive, and technology exhibits constant returns to scale; this fixes the capital/labor ratio and, consequently, the wage rate per efficiency unit of labor. In addition, due to exogenous inter-country productivity differentials, the equilibrium wage rate in our economy is lower than in the developed nation(s). As a result, migration prospects tend to increase the expected return to human capital in the developing country, thus inducing more people to invest in education. Assume that people are initially endowed with a given level of inherited human capital, live for two periods, and make two decisions: whether to invest in education during their youth; and whether to migrate in adulthood. It is convenient to model the education decision as a "take it or leave it" choice, involving a unique educational program, $\bar{e}$. Assume also that this minimal degree of education is a necessary (but not sufficient) condition for migration to a high-wage destination. The common justification for the latter assumption is that the educational attainment $\bar{e}$ could be set as a prerequisite by immigration authorities, who then randomly select migrants (in proportion $m$ ) among the appropriate candidates. ${ }^{10}$ This assumption is consistent with the recent quality-

\footnotetext{
${ }^{10}$ Another possibility would be to assume that education is a continuous variable, and makes it easier to obtain an immigration visa. In that case, $m$ would have been a function of $e$, with $m^{\prime}>0$. However, to the extent that education is not a perfect signal of individual skills and there are different educational thresholds, each of them associated with a different migration probability,
} 
selective orientation of immigration policies in most OECD countries, as detailed in the introduction.

In keeping with Mountford (1997) and Beine et al. (2001), individuals are assumed to be born with heterogeneous learning abilities: each individual is characterized by his or her personal ability, with the cost of achieving the educational prerequisite, $c$, decreasing with personal ability. Denoting by $a$ the individual ability to learn, the population distribution in country $i$ is described by the density function $f_{i}(a)$ defined on $R^{+}$, or by the cumulative distribution $F_{i}(a)$. The cost of achieving the minimal education threshold, $c$, also depends on a set of country-specific variables affecting human capital formation in a given country (e.g., public expenditures in education). Let us denote this set of variables by $\chi_{i}^{h}$. Hence: $c_{i}(a)=c\left(a, \chi_{i}^{h}\right)$, with $c_{a}^{\prime}<0$.

The return to education is measured by the relative wage premium for the educated (relatively to the non-educated). Denoting by $m_{i}$ the probability that an educated agent from country $i$ would migrate to a high-wage destination and by $\left(1-m_{i}\right)$ his/her probability to remain in the origin country, the expected return to education, $r l_{i}$, may be written as a weighted average of the relative return abroad, $\omega^{*}$, and the relative return in the domestic country, $\omega_{i}^{d}$ :

$$
\operatorname{rel}_{i}=m_{i} \omega^{*}+\left(1-m_{i}\right) \omega_{i}^{d}
$$

with $\omega^{*}>\omega_{i}^{d}$, implying that $\frac{\partial r e l_{i}}{\partial m_{i}}>0$. Recall that under the general assumptions above, $\omega^{*}$ and $\omega_{i}^{d}$ are constant.

To concentrate on internal solutions, assume that some individuals are educated. Since the cost of acquiring education decreases with individuals' learning abilities and the return to education is constant, the equilibrium proportion of uneducated agents among the younger generation in country $i$ is given by $F_{i}\left(a_{i}^{*}\right)$, with $a_{i}^{*}$ denoting the ability of the agent indifferent as to whether to invest in education. Therefore, the equilibrium proportion of educated agents in country $i$ is given by:

$$
H_{i}=1-F\left(a_{i}^{*}\right)
$$

As shown in Figure 1, an increase in the migration probability increases the expected return to education, thus shifting the critical ability threshold to the left. Clearly, the critical ability is a function of $m_{i}, \omega^{*} / \omega_{i}^{d}$ and $\chi_{i}^{h}$.

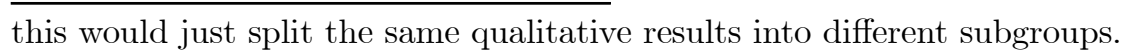




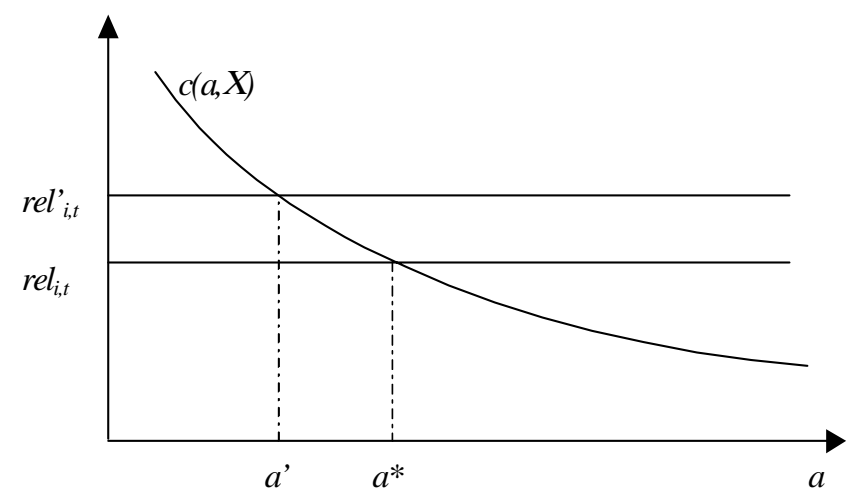

We model endogenous growth by assuming an intergenerational human capital extermality; more precisely, we assume that education investments within a given generation translate into a higher initial level of human capital to be inherited by the following generation. The growth rate of human capital in a country is therefore positively affected by the ex-post proportion of educated workers within the previous generation (i.e., once migration has been netted out). This proportion, denoted by $h_{u m}$, is given by:

$$
\operatorname{hum}_{i}=\frac{\left(1-m_{i}\right)\left[1-F\left(a_{i}^{*}\right)\right]}{1-m_{i}\left[1-F\left(a_{i}^{*}\right)\right]}=\frac{\left(1-m_{i}\right) H_{i}}{1-m_{i} H_{i}}
$$

However, the growth rate is also potentially affected by a number of other countryspecific variables, such as the stock of physical capital, R\&D expenditures, and public infrastructures. Let us denote this set of country-specific variables $\chi_{i}^{g}$. The human capital growth rate equation may thus be written as:

$$
g_{i}=g\left[h u m_{i}, \chi_{i}^{g}\right]
$$

In such a framework, emigration has two opposite effects captured in the expression of hum $_{i}$. On the one hand, migration opportunities increase the expected return to education and, therefore, induce more people to invest in education; we refer to this first effect as to a "brain effect". On the other hand, emigration reduces the stock of human capital left in the sending country; we refer to this second effect as to a "drain effect". These two effects are apparent on Figure 2: a rise in $m_{i}$ moves the critical ability to the left, thereby increasing the number of individuals who choose to invest in education. However, only a proportion $\left(1-m_{i}\right)$ of this greater number 
of educated individuals actually remain in the home country, so that the sign of the overall effect depends on which effect dominates.

Figure 2: The proportion of educated agents staying put

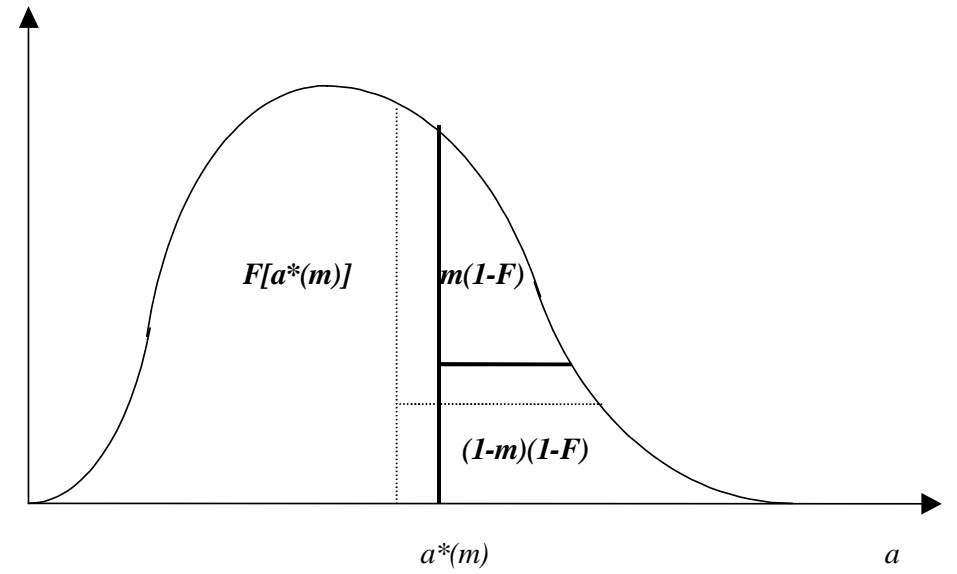

The main result of this simple model is expressed by the following proposition:

Proposition 1 The total growth effect of the brain drain is given by $\frac{d g_{i}}{d m_{i}}=\frac{\partial g_{i}}{\partial \text { umm }_{i}} \times$ $\left[\frac{-\left[1-F\left(a_{i}^{*}\right)\right] F\left(a_{i}^{*}\right)}{\left\{1-m_{i}\left[1+F\left(a_{i}^{*}\right)\right]\right\}^{2}}+\frac{\left(1-m_{i}\right) F_{a}^{\prime}\left(-\frac{\partial a_{i}^{*}}{\partial m_{i}}\right)}{\left\{1-m_{i}\left[1+F\left(a_{i}^{*}\right)\right]\right\}^{2}}\right] \gtrless 0$, with the first term between brackets measuring the (detrimental) drain effect and the second term between brackets measuring the (beneficial) brain effect.

Proof. This is straightforward when deriving (4) with respect to $m_{i}$, and rearranging the terms

\section{$2.2 \quad$ The empirical model}

The two main variables in the above theoretical model have fairly observable empirical

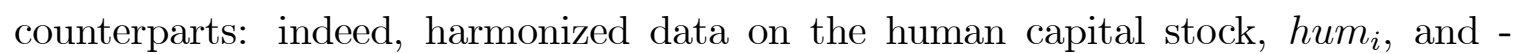
thanks to Carrington and Detragiache (1998) -, on the migration rates of the highly educated, $m_{i}$, are available for a large set of developing countries. Also, the vectors of additional explicative variables, $\chi_{i}^{h}$ and $\chi_{i}^{g}$, may be built so as to include variables for which there are harmonized international data. The ex-ante proportion of the educated in the population (before migration has been netted out), $H_{i}$, is clearly not 
observable but may easily be approached on the basis of equation (3) using current observations for hum $_{i}$ and $m_{i}$ :

$$
H_{i}=\frac{h^{\prime} m_{i}}{1-m_{i}\left(1-\text { hum }_{i}\right)}
$$

The following system of equation forms our basic econometric model:

$$
\begin{aligned}
\Delta H_{i}+d_{H} H_{i, l a g} & =\psi\left(m_{i} ; \chi_{i}^{h} ; \epsilon_{i}^{h}\right) \\
g_{i} & =\gamma\left(\text { hum }_{i} ; \chi_{i}^{g} ; \epsilon_{i}^{g}\right)
\end{aligned}
$$

where $\Delta H_{i}=H_{i}-H_{i, l a g}$ measures the formation of human capital in country $i$, $H_{i, l a g}$ is the lagged value of $H_{i}, d_{H}$ is the depreciation rate (educated agents leaving the labor force), and $\epsilon_{i}^{h}$ and $\epsilon_{i}^{g}$ are the error terms in the equations of $H$ and $g$, respectively.

In what follows, we choose an analytical specification for these equations, and estimate their parameters so as to evaluate the global effect of the brain drain and sign the expected growth effect of a marginal increase in the migration probability for each country.

After completing the estimation procedure, a potentially interesting insight of this model is the evaluation of the closed economy stock of human capital $\left(\widetilde{H}_{i}\right)$, that is, the stock of human capital that would be obtained for a given country would its emigration rate had been set to zero. Since this stock must be non-negative, we have:

$$
\widetilde{H}_{i}=\operatorname{Max}\left\{\psi\left(0 ; \chi_{i}^{h} ; \epsilon_{i}^{h}\right)+\left(1-d_{H}\right) H_{i, l a g} ; 0\right\}
$$

Substituting (5) and (6) in (7) gives:

$$
g_{i}=\gamma\left(\frac{\left(1-m_{i}\right)\left[\psi\left(m_{i} ; \chi_{i}^{h} ; \epsilon_{i}^{h}\right)+\left(1-d_{H}\right) H_{i, l a g}\right]}{1-m_{i}\left[\psi\left(m_{i} ; \chi_{i}^{h} ; \epsilon_{i}^{h}\right)+\left(1-d_{H}\right) H_{i, l a g}\right]} ; \chi_{i}^{g} ; \epsilon_{i}^{g}\right)
$$

Hence, the growth effect of a marginal increase in the migration probability is given by:

$$
\frac{\partial g_{i}}{\partial m_{i}}=\gamma_{i}^{\text {hum }} \times \frac{-H_{i}\left(1-H_{i}\right)+\psi_{i}^{m}\left(1-m_{i}\right)}{\left(1-m_{i} H_{i}\right)^{2}}
$$

where $\gamma_{i}^{\text {hum }}$ measures the derivative of $\gamma$ with respect to hum in country $i$, and $\psi_{i}^{m}$ the derivative of $\psi$ with respect to $m$ in country $i$. Clearly, this last equation is the empirical counterpart of the result presented in Proposition 1. 
This framework allows us to address three questions which are central in the brain drain literature:

- Is there a possibility of a beneficial brain drain for country $i$ ?

- What is the net current effect of the brain drain in country $i$ ?

- Would an increase in the migration probability of the highly educated stimulate growth in country $i$ ?

The following corollaries of Proposition 1 provide the answers to these questions:

Corollary 1 A brain drain may be beneficial to country $i$ if and only if $\psi_{i}^{m}\left(0 ; \chi_{i}^{h} ; \epsilon_{i}^{h}\right)>$ $\widetilde{H}_{i}\left(1-\widetilde{H}_{i}\right)$.

Proof. This condition implies that the numerator of (9), evaluated at $m_{i}=0$, is positive. This is a sufficient (but not necessary) condition

Providing that the latter condition holds, a sufficiently small positive migration probability stimulates growth in country $i$ compared to the closed-economy case.

Corollary 2 The net growth effect of the brain drain is measured by $\Delta g_{i}=\gamma\left(\right.$ hum $\left._{i} ; \chi_{i}^{g} ; \epsilon_{i}^{g}\right)-$ $\gamma\left(\widetilde{H}_{i} ; \chi_{i}^{g} ; \epsilon_{i}^{g}\right)$.

Proof. Obvious when comparing the growth rates with and without migration

Corollary 3 A marginal increase in the migration probability of the highly educated is beneficial to country $i$ if and only if $\psi_{i}^{m}\left(m_{i} ; \chi_{i}^{h} ; \epsilon_{i}^{h}\right)>\frac{H_{i}\left(1-H_{i}\right)}{1-m_{i}}$.

Proof. This condition implies that the numerator of (9) is positive at the current observed migration rate

With these understandings, we turn to data and specification issues before presenting the results of the estimation procedure. 


\section{The brain drain estimates}

As explained above, the empirical analysis of the growth effects of the brain drain has so far been hampered by the lack of reliable comparative data on migration rates by education levels. Such data is now available thanks to Carrington and Detragiache's estimates of migration rates for 61 developing countries and three educational levels. A quick look at the CD migration data immediately reveals two interesting features. First, it is indeed the case that migration rates are higher for the highly educated, confirming that the probability of emigration strongly increases with educational attainments. Secondly, the brain drain is a general phenomenon, at work for all types of developing countries (large and small) from all regions.

Carrington and Detragiache (1998) used three main statistical sources to construct their database, and had to rely on a number of assumptions to extrapolate some data as well. Since our analysis relies so heavily on their estimates, we detail in this section the procedure they used and explain how we are trying to cope with the possible drawbacks of their approach.

Basically, three steps may be distinguished in the construction of the CD data:

Step 1: Computation of US immigration stock by origin country and educational level (denoted by $I_{i, s}^{U S}$ ) and non-US OECD immigration stock by origin country (denoted by $I_{i}^{N o n-U S}$ )

This first step is based on the 1990 US census which provides detailed information on US immigrants by country of origin $(i)$ and educational level $(s)$. Three education levels are distinguished: primary (0-8 years of schooling), secondary (9-12 years of schooling) and tertiary (13 years of schooling or more). This information is extrapolated from a 5 percent sample of the Census data and concerns individuals aged 25 or more so as to exclude most foreign students temporarily residing in the US. Summing over educational categories gives the total US immigration stock by country of origin:

$I_{i}^{U S}=\sum_{s} I_{i, s}^{U S}$. Clearly, illegal immigrants cannot be counted, but this should not excessively distort the estimates for the highly educated.

The immigration stocks in non-US OECD countries are extracted from the "Trends in international migration" published by the OECD. It should be noted that the comparison with the US Census data is not perfect. These OECD statistics do not report the migrants' educational attainment nor their age. Moreover, for small countries, the estimates of non-US OECD immigration may be seriously understated since most 
receiving nations only record immigrants for the top five or ten sending countries.

\section{Step 2: Computation of emigration stocks by origin country and edu- cational level (denoted by $I_{i, s}$ )}

To evaluate the total stock of emigrants for a country and its distribution across educational levels, Carrington and Detragiache (1998) assume that non-US OECD immigrants from a given country are distributed across educational categories as do US immigrants from that country. This implies: $I_{i, s}=I_{i, s}^{U S}+\frac{I_{i, s}^{U S}}{I_{i}^{U S}} I_{i}^{N o n-U S}$, which is a very strong assumption for developing countries for which the US is not an important migration destination. This problem is serious if the US and the other destination countries differ substantially in their immigration policies on the issue of quality-selection. Finally, emigrants to non-OECD countries, such as the educated manpower that emigrated from many developing countries to the Gulf states, are not included in the data. This might lead for some countries to an under-estimation of the number of their emigrants.

\section{Step 3: Computation of emigration rates by origin country and educa-} tional level (denoted by $m_{i, s}$ )

The last step is to evaluate emigration rates by educational levels for each origin country. This is done through comparing the number of migrants from each educational category to the populations from which they are drawn (denoted by $N_{i, s}$ ). The emigration rate is then given by $m_{i, s}=\frac{I_{i, s}}{N_{i, s}+I_{i, s}}$.

Population sizes by education levels are computed from the Penn World Tables (total population size), the United Nations Demographic Yearbook (share of the population aged 25 and over), and the Barro and Lee (1993) data set on educational attainments. Three limits should be mentioned at this stage. First, for countries where data are not available, continent-wide averages have been imputed. Secondly, some mapping is necessary to reconcile the concepts of the Barro and Lee database with those of the Schooling Census used by Carrington and Detragiache. Finally, emigrants are likely to be counted as part of the population size $\left(N_{i s}\right)$ in some home countries. Thus, an alternative measure of the migration rate - the ratio $I_{i s} / N_{i s}-$ offers an upper bound that may be compared to the lower benchmark bound to be used for our analysis. 
Table 1: Migration rate of skilled workers per country of origin

\begin{tabular}{|c|c|c|c|c|c|}
\hline Code & Country & $\begin{array}{l}\text { Brain drain } \\
\text { (in \%) }\end{array}$ & $\begin{array}{c}\text { Migration rate } \\
\text { (in \%) }\end{array}$ & $\begin{array}{c}\text { US Immigrants } \\
\text { (in volume) }\end{array}$ & $\begin{array}{c}\text { US Im migrants } \\
\text { (in \% of OECD) }\end{array}$ \\
\hline \multicolumn{6}{|c|}{ PART A: Limited sample with highly reliable countries $(30$ countries) } \\
\hline Guy & Guyana & 77,5 & 14,5 & 61936 & 100,0 \\
\hline Jam & Jamaica & 77,4 & 20,3 & 159913 & 61,0 \\
\hline Tat & Trinitad-Tobago & 57,8 & 9,5 & 65810 & 100,0 \\
\hline Sal & El Salvador & 26,1 & 11,3 & 263625 & 100,0 \\
\hline Gha & Ghana & 25,7 & 0,4 & 12544 & 53,3 \\
\hline Pan & Panama & 19,6 & 6,7 & 68583 & 100,0 \\
\hline $\mathrm{Nic}$ & Nicaragua & 18,8 & 4,7 & 61168 & 100,0 \\
\hline Hon & Honduras & 15,7 & 3 & 54346 & 100,0 \\
\hline Kor & South Korea & 14,9 & 4,2 & 377940 & 36,0 \\
\hline Dom & Dominican Rep. & 14,7 & 6,5 & 187871 & 96,7 \\
\hline Gua & Guatemala & 13,5 & 3,4 & 127346 & 100,0 \\
\hline Mex & Mexico & 10,3 & 7,7 & 2743638 & 100,0 \\
\hline Phi & Philippines & 9 & 3,1 & 728454 & 71,6 \\
\hline $\mathrm{CR}$ & Costa Rica & 7,1 & 2,4 & 28784 & 100,0 \\
\hline Pak & Pakistan & 6,7 & 0,3 & 52717 & 35,2 \\
\hline Chl & Chile & 6 & 1,1 & 36252 & 54,3 \\
\hline Col & Colombia & 5,8 & 1,1 & 162739 & 96,9 \\
\hline Egy & Egypt & 5 & 0,5 & 53261 & 50,6 \\
\hline Bol & Bolivia & 4,2 & 0,7 & 18772 & 100,0 \\
\hline Ecu & Ecuador & 3,8 & 1,9 & 89336 & 100,0 \\
\hline Uru & Uruguay & 3,8 & 1,1 & 15716 & 100,0 \\
\hline Per & Peru & 3,4 & 1 & 86323 & 87,1 \\
\hline Chn & China & 3 & 0,1 & 404579 & 51,5 \\
\hline Arg & Argentina & 2,7 & 0,6 & 64080 & 72,3 \\
\hline Ind & India & 2,6 & 0,2 & 304030 & 44,1 \\
\hline Ven & Venezuela & 2,1 & 0,4 & 22634 & 77,4 \\
\hline Par & Paraguay & 2 & 0,2 & 4313 & 100,0 \\
\hline Indo & Indonesia & 1,5 & na & 32172 & 90,5 \\
\hline Tha & Thailand & 1,5 & 0,2 & 53118 & 87,6 \\
\hline Bra & Brazil & 1,4 & 0,2 & 53904 & 44,0 \\
\hline \multicolumn{6}{|c|}{ Part B: Small countries with missing non-US immigration data (21 countries) } \\
\hline Gam & Gambia & 61,4 & 0,2 & 747 & 100,0 \\
\hline SL & Sierra Leone & 24,3 & 0,3 & 4155 & 100,0 \\
\hline $\mathrm{Fi}$ & Fiji & 21,3 & 3,6 & 11420 & 100,0 \\
\hline $\mathrm{Ug}$ & Uganda & 15,5 & 0,1 & 5060 & 100,0 \\
\hline Ken & Kenya & 10 & 0,1 & 8372 & 100,0 \\
\hline Moz & Mozambique & 8,6 & na & 920 & 100,0 \\
\hline Mau & Mauritius & 7,2 & 0,2 & 1100 & 100,0 \\
\hline Zam & Zambia & 5 & 0,1 & 1613 & 100,0 \\
\hline Zim & Zimbabwe & 4,7 & 0,1 & 3161 & 100,0 \\
\hline Cam & Cameroon & 3,2 & na & 1694 & 100,0 \\
\hline Syr & Syria & 3 & 0,7 & 27504 & 100,0 \\
\hline Les & Lesotho & 2,9 & na & 160 & 100,0 \\
\hline Png & Papua-NG & 2,2 & na & 480 & 100,0 \\
\hline Rwa & Rwanda & 2,2 & na & 200 & 100,0 \\
\hline Malw & Malawi & 2 & na & 381 & 100,0 \\
\hline Sud & Sudan & 1,8 & na & 2496 & 100,0 \\
\hline CAR & Central African Rep. & 1,7 & na & 160 & 100,0 \\
\hline Tog & Togo & 1,3 & na & 460 & 100,0 \\
\hline Mali & Mali & 0,9 & na & 220 & 100,0 \\
\hline Con & Congo & 0,5 & na & 200 & 100,0 \\
\hline Ben & Benin & 0,4 & na & 180 & 100,0 \\
\hline \multicolumn{6}{|c|}{ Part C: Countries with a share of US emigrants lower than $30 \%$ (8 countries) } \\
\hline Tun & Tunisia & 63,3 & 8,6 & 2816 & 1,1 \\
\hline $\mathrm{Alg}$ & Algeria & 55 & 6,3 & 3904 & 0,6 \\
\hline Sen & Senegal & 47,7 & 2,4 & 1370 & 2,0 \\
\hline Tur & Turkey & 46,2 & 8,5 & 43605 & 1,9 \\
\hline SrL & Sri Lanka & 23,6 & 0,8 & 8751 & 14,1 \\
\hline Mal & Malaysia & 22,7 & 1,2 & 15261 & 18,2 \\
\hline SA & South Africa & 7,9 & 0,4 & 22678 & 32,4 \\
\hline Ban & Bangladesh & 2,5 & 0,1 & 12385 & 25,9 \\
\hline
\end{tabular}

Source: Carrington and Detragiache (1998) 


\section{Summary}

The brain drain data computed by Carrington and Detragiache (1998) gives us an idea of the stock, rather than the flows, of educated migrants. Moreover, since their estimates are available for 1990 only, time-series investigation is excluded. Table 1 summarizes the CD estimates for the variables defined above: the share of emigrants among the highly educated $\left(m_{i, s}\right)$, the global migration rate in percent $\left(\frac{I_{i}}{N_{i}+I_{i}}\right)$, and the total stock of US immigrants $\left(I_{i}^{U S}\right)$ both in volume and in percent of OECD immigrants $\left(\frac{I_{i}^{U S}}{I_{i}}\right)$. Their sample includes 59 developing countries. As apparent from Table 1, we have chosen to split the CD sample into three sub-samples which differ in terms of data quality. ${ }^{11}$ Part A lists the countries for which information is most reliable, that is, for which the US is a major migration destination. The countries for which migratory flows to non-US OECD countries are either not available or underestimated are easily identifiable in the CD data set since they appear erroneously with $100 \%$ of their emigrants choosing the US as their destination. For some countries (e.g., Latin American countries), this may be a plausible approximation, and in this case these countries appear in Part A of Table 1; for other countries (e.g., sub-Saharan African countries), this is clearly implausible, and in this case these countries appear in Part B of Table 1. Finally, Part C contains the countries for which the US is clearly not the main emigration destination, that is, less than one-third of their emigrants choose the US as their destination. ${ }^{12}$

\section{Empirical analysis}

To evaluate the "brain effect" described in equation (6), the gross formation of human capital between 1985 and $1990\left(\Delta H_{i}+d_{H} H_{i, l a g}\right)$ is expressed as a function of several explanatory variables:

- The expected foreign return to high education, whose weight depends on wage differentials and the probability of migration; as explained in the theoretical section, the latter is assumed to be given by the current proportion of emigrants among the highly educated in the home country, $m_{i}$;

\footnotetext{
${ }^{11}$ See also Section 6.1 for additional justification for this selection procedure.

${ }^{12}$ In the robustsness analysis in Section 6.1., we also restrict the analysis to countries where this share is greater than $50 \%$.
} 
- The cost of acquiring education, which itself depends on public expenditures in education, denoted by highex ${ }_{i}$ and eduex $_{i}$;

- Workers' remittances, rem $_{i}$, which may alleviate liquidity constraints impeding investments in human capital; in addition, in the absence of statistics on return migration, they also provide an indirect means of controlling for possible returns in subsequent periods, since preparing one's return is known to be a central motivation to remit; ${ }^{13}$

- Other control variables; notably, we have used indicators of political tensions and ethnic diversity (avelf, gunn1 and gunn2), along the lines suggested by Easterly and Levine (1997).

Two assumptions were made to facilitate the analysis. First, the depreciation rate of human capital, which expresses the proportion of educated people leaving the labor force during a given period (1985-90 in our case), has been set at $10 \% .{ }^{14}$ Secondly, since migration rates by educational attainments are available for the year 1990 only, it is impossible to determine the exact value of $H_{i, L a g}$ and, therefore, to compute the investment in human capital, $\Delta H_{i}$, in a direct manner. However, recall that in our analysis, migration rates measure stocks rather than flows; for this reason, it seems reasonable to assume that the ratio $H_{i} / h_{u m}$ did not change much between 1985 and 1990.

With these understandings, the basic equation of human capital formation may be written as:

$$
\Delta H_{i}+d_{H} H_{i, l a g}=\psi\left(m_{i}, \text { rem }_{i}, \text { highex }_{i}, \text { gunn }_{i}, \text { eduex }_{i}, \text { avel }_{i} ; \epsilon_{i}^{h}\right)
$$

To evaluate the "drain effect" described in equation (7), we regressed the average growth rates over the period 1985-95 on a set of explanatory variables:

- The ex-post human capital stock (that is, after migration has been netted out), $h_{u m}, t$, measured at the beginning of each period (i.e, in 1985 and 1990);

\footnotetext{
${ }^{13}$ It is well recognized that remittances per head decline as migrants become more integrated in the host economy, although such a decline is only gradual (see, e.g., Funkhouser, 1995). Such a motivation, however, is less likely for the highly-educated, precisely because they are relatively well integrated abroad.

${ }^{14}$ Computations with other possible values for the depreciation rate of human capital did not affect the results.
} 
- Indicators of the quantity of physical capital, like the number of telephones per worker $\left(\right.$ phones $\left._{i}\right)$, as suggested by Easterly and Levine (1997);

- Workers' remittances, since these may also alleviate credit constraints impeding private investments in physical capital;

- Institutional indicators of ethnic diversity (gunn $\left.2_{i}\right)$ and political instability $\left(\right.$ assass $\left._{i}\right)$, which were found to have significant growth effects in Easterly and Levine (1997);

- The $\log$ of initial GDP $\left(\log y_{i, t}\right)$ for each period so as to test for convergence over the period 1985-95;

- Regional dummies for Sub-Saharan African $\left(s s a_{i}\right)$ and Latin American $\left(l_{a} t_{i}\right)$ countries, which were found significantly related to growth performances in Easterly and Levine (1997).

The basic growth equation is therefore given by:

$$
g_{i, t}=\gamma\left(\text { hum }_{i, t}, \text { phones }_{i}, \text { rem }_{i}, \text { gunn }_{i}, \text { assass }_{i}, \log _{i, t}, \text { ssa }_{i}, \text { lat }_{i} ; \epsilon_{i}^{g}\right)
$$

where $g_{i}$ denotes the average annual growth rate over the investigated period (19851995) in country $i$.

Note that we have two time-series obervations for $g_{i, t}, \log y_{i, t}$ and $h u m_{i, t}$, allowing us to carry out a panel-data regression analysis; the rest of the explanatory variables, however, are time-invariant.

Table 2 indicates the symbols used for all the variables used or tested in our analysis, their empirical counterparts, and the data sources. ${ }^{15}$

\footnotetext{
${ }^{15}$ Some of these variables did not prove to be significant or were dominated by another control of the same nature. In that case, they will not appear in the result tables below.
} 
Table 2 : Variables definition and empirical counterparts

\begin{tabular}{|c|c|c|c|}
\hline Variable & Definition & Empirical counterparts & Statistical sources \\
\hline$m$ & $\begin{array}{l}\text { Migration rate of high skilled } \\
\text { workers }\end{array}$ & $\begin{array}{l}\text { Migration rate to OECD, tertiary } \\
\text { schooling level - } 1995\end{array}$ & $\begin{array}{l}\text { Carrington and Detragiache } \\
\text { (1998) }\end{array}$ \\
\hline diff & $\begin{array}{l}\text { GDP differential with OECD } \\
\text { countries }\end{array}$ & $\begin{array}{l}\text { GDP differential with respect to } \\
\text { average G7 countries - } 1990\end{array}$ & Chelem Database- OECD \\
\hline dens & Population density & Population density - 1990 & World Bank \\
\hline hum & $\begin{array}{l}\text { Ex-post proportion of highly } \\
\text { educated }\end{array}$ & $\begin{array}{l}\text { Highest school attainment in } \% \text { of } \\
\text { total population - } 1990\end{array}$ & Barro and Lee (1993) data set \\
\hline humlag & $\begin{array}{l}\text { Lagged ex-post proportion of } \\
\text { highly educated }\end{array}$ & $\begin{array}{l}\text { Highest school attainment in } \% \text { of } \\
\text { total population - } 1985\end{array}$ & Barro and Lee (1993) data set \\
\hline eduex & $\begin{array}{l}\text { Public expenditures in } \\
\text { education }\end{array}$ & $\begin{array}{l}\text { Public expenditures in education } \\
\text { in } \% \text { of GDP - } 1980\end{array}$ & United Nations (1997) \\
\hline highex & $\begin{array}{l}\text { Share of expenditures - higher } \\
\text { education }\end{array}$ & $\begin{array}{l}\text { Expenditures in higher education } \\
\text { in \% of total expenditures - 1990- } \\
1994\end{array}$ & United Nations (1997) \\
\hline$g d p$ & GDP per head level & $\begin{array}{l}\text { Level of GDP per head in PPP } \\
\text { units - 1990-1980 }\end{array}$ & Chelem Database- OECD \\
\hline$g$ & Growth rate & $\begin{array}{l}\text { Growth rate of GDP per head in } \\
\text { PPP units - average 1985-1995 }\end{array}$ & Chelem Database- OECD \\
\hline rem & Workers'remittances & $\begin{array}{l}\text { Workers' remittances in } \% \text { of } \\
\text { GDP- } 1990\end{array}$ & IMF-IFS database \\
\hline elife & Life Expectancy at birth & Life expectancy - 1992 & World bank \\
\hline avelf & $\begin{array}{l}\text { Composite indicator of ethnic } \\
\text { diversity }\end{array}$ & $\begin{array}{l}\text { Based on } 5 \text { measures of ethnic } \\
\text { diversity }\end{array}$ & Easterly and Levine (1997) \\
\hline gunn 1 & Indicator of ethnic diversity & $\begin{array}{l}\text { Population in } \% \text { not speaking the } \\
\text { official language - } 1991\end{array}$ & Gunnemark (1991) \\
\hline gunn2 & Indicator of ethnic diversity & $\begin{array}{l}\text { Population in \% not speaking the } \\
\text { most widely used language - } 1991\end{array}$ & Gunnemark (1991) \\
\hline racial & Indicator of racial tension & Racial tension - 1984 & $\begin{array}{l}\text { The International Country Risk } \\
\text { Guide }\end{array}$ \\
\hline assass & Indicator of political stability & $\begin{array}{l}\text { Number of political murders per } \\
1000 \text { inhabitants - } 1980-89\end{array}$ & Banks (1994) \\
\hline purges & Indicator of political stability & $\begin{array}{l}\text { Systematic elimination of political } \\
\text { opponents - 1980-89 }\end{array}$ & Banks (1994) \\
\hline warciv & Indicator of political stability & Civil war, dummy variable - 80's & Sivard (1993) \\
\hline road & Indicator of infrastructure & Paved roads in $\%$ of total & Easterly and Levine (1997) \\
\hline phone & Indicator of technology & $\begin{array}{l}\text { Log of telephones per } 1000 \\
\text { workers }\end{array}$ & Easterly and Levine (1997) \\
\hline рор & Population & Population - 1990 & United Nations (1997) \\
\hline SubSah & $\begin{array}{l}\text { Dummy for Sub-saharian } \\
\text { African countries }\end{array}$ & - & - \\
\hline LatAm & $\begin{array}{l}\text { Dummy for Latin American } \\
\text { countries }\end{array}$ & - & - \\
\hline
\end{tabular}

\subsection{Econometric issues}

Before we carry out the estimations, we first address some specification issues. A first important question concerns the exogeneity of the migration probability used in the econometric analysis. When trying to determine the impact of migration on 
education, one has to control for the reverse effect since, on average, a larger share of educated agents is likely to cause higher migration rates. For this reason, the exogeneity of the migration probability may be questioned.

In an attempt to cope with this issue, recent empirical growth analyses (e.g., Barro and Sala-I-Martin, 1995, Hall and Jones, 1999) have been concerned with the use of truly exogenous instruments. Along the lines suggested in these studies, the following variables could be retained as potential candidate explanatory variables in a first-stage migration equation: population density in the source country $\left(\right.$ dens $\left._{i}\right)$ as a proxy for soil occupation, and life expectancy at birth $\left(\right.$ lif $\left.e_{i}\right)$ as a proxy for general living conditions. Another potential instrument variable is the country's population size $\left(p_{0} p_{i}\right)$; this stems from a basic feature of the immigration policy of the United States in the past, which was based on a quota system. Although such quotas do not officially exist any more, one may suspect that in practice, immigration restrictions are less binding for small countries, as found by Beine et al. (2001). Furthermore, racial tensions $\left(\right.$ racial $\left._{i}\right)$ were also taken into account, as well as the (log of the) stock of migrants of the origin country in OECD countries $\left(l_{s t o c k_{i}}\right)$. The latter variable (measured by the absolute size of the migration network in the CD database) is expected to display a positive relationship with migration flows: a larger network at destination is thought to be associated with lower migration (especially informationrelated) costs and, therefore, is expected to increase the number of current migrants. ${ }^{16}$ Finally, the GDP per capita of the source country - expressed as a proportion of the average GDP per capita of the G7 countries $\left(\right.$ diff $\left.f_{i}\right)$ - is a good proxy for wage differentials which are supposed to be a driving force of migration.

In our first-stage migration equation, we selected four out of the six abovementioned variables and eliminated two variables for which there is a strong presumption of a correlation with the human capital stock: wage differentials, for obvious reasons, ${ }^{17}$ and life expectancy, the exogeneity of which being questionable given the fact that longer-lived individuals can enjoy the benefits from education over a longer period. Life-expectancy may well be a useful instrument in amenity-based models of migration, but this is probably not the case when differentials in returns to education are a central migration motive, as is the case here. We are therefore left

\footnotetext{
${ }^{16}$ Such network effects have first been recognized in the sociological literature (e.g., Massey et al., 1994) and, more recently, in the economic literature (e.g., Carrington et al., 1996, Munshi, 2003).

${ }^{17}$ In addition - and as a crude test -, the correlation between $\operatorname{dif} f_{i}$ and $H_{i}$ turned out to be higher than 0.5 .
} 
with four potential instrument variables: the population density, the total population size, racial tensions, and the stock of migrants at destination.

At a theoretical level, it could legitimately be argued that some of these potential instruments somehow affect the incentives to invest in education. Some may also affect income levels and, hence, people's ability to pay for education services. For example, one may argue that in densely populated areas, the average distance to school and, consequently, the indirect cost of education, is probably lower. However, this would seem to be less a serious problem for higher education given the relatively small number of higher education institutions in developing countries and the tendency for students enrolled in such institutions to live close-to or on-campus. Regarding total population, we could not think of direct reasons why the size of a country's population should be correlated with that country's education level. By contrast, it could well be that the score of racial tensions impacts on human capital formation, especially when ethnic discrimination is a serious issue. ${ }^{18}$ However, since this is likely to be the case only in a limited number of countries, we choose to let the data tell us whether this variable could reasonably be considered as a valid instrument. Finally, there is no a priori reason why migration networks at destination should impact on human capital formation beyond their effect on migration prospects and incentives (captured by our instrumentation equation).

At an empirical level, the validity of our instruments rests on two conditions: the instruments should first be significantly correlated with the migration rate, and the exogeneity condition requires that they should be uncorrelated with the error term in $(10)$.

The following equation(12) reports the results of the OLS regression of the migration equation for the full sample on the four instruments retained (t-statistics are reported between brackets):

$$
\begin{aligned}
m_{i} & =\underset{(-0.79)}{-0.082}+\underset{(5.90)}{0.061} \text { lstock } \underset{(-0.16)}{0.003} \text { dens }_{i}-\underset{(-6.40)}{0.098} \text { pop }_{i}-\underset{(-2.89)}{0.036} \text { racial }_{i} \\
R^{2} & =0.561 ; F=14.400 ; \text { Nobs }=50 .
\end{aligned}
$$

Regardless of the measure retained for migration rates (lower or upper bound), ${ }^{19}$ the four instruments were found significant at least at a $10 \%$ significance level in the

\footnotetext{
${ }^{18}$ Note that this indicator ranges from 1 (high tension) to 6 (low tension).

${ }^{19}$ The results using the upper bound are available upon request.
} 
full sample, except dens $s_{i}$ which turned out to be significant only for a subset of countries (see Section 6) and was therefore kept throughout the analysis. Interestingly, population size enters with a negative sign; this supports the conjecture mentioned above, according to which immigration restrictions are more binding for larger countries. In turn, this further justifies the assumption that education decisions are taken in a context of uncertainty regarding future migration opportunities, as asssumed in the theoretical model. Note also that the signs of racial $_{i}$ and lstock $_{i}$ are in keeping with intuition: greater racial tensions (a lower score) and a higher initial stock of migrants both stimulate emigration. Together, the variables $l s t o c k_{i}$, pop $_{i}$ and racial $_{i}$ account for more than $56 \%$ of the migration variability, which is quite satisfactory from a cross-sectional perspective.

A more formal test relies on the value of the $F$ statistics testing the null hypothesis that all coefficients in (12) jointly equal zero. The test reveals that this null hypothesis is strongly rejected, suggesting that the four variables are strong rather than weak instruments. Given that we have more instruments than endogeneous variables, a $J$-test of overidentification was also run to assess the exogeneity property of the retained instruments. The $J$-test relies on a $F$-test of exclusion of the four instruments retained in the OLS model (regressing the residuals from the IV estimation on instruments and exogeneous variables). Under the null hypothesis of exogeneity, the $J$-test statistics follows a $\chi_{m-k}^{2}$ distribution with $m$ being the number of instruments ( 4 throughout the rest of the paper) and $k$ the number of endogeneous variables (1 except in section 6.2). The $J$-test statistic is given in the result tables below. In each specification, the test strongly supports the exogeneity assumption of the four instruments, thus providing some confidence that our instruments are indeed uncorrelated with the human capital variable.

\subsection{Full-sample estimation results}

We now turn to the estimation of our basic system (equations (10)-(11)). The first equation is estimated through instrumental variables, while the second equation is estimated by panel OLS regression. ${ }^{20}$ The number of instruments (including a constant) and explanatory variables imply that equation (10) is over-identified. In both

\footnotetext{
${ }^{20}$ Since the two equations share some common regressors, another candidate estimation technique is the seemingly unrelated regressions (SURE). Using SURE, we obtained fairly similar point estimates and significance levels.
} 
equations, the constant term turned out to be non-significantly different from zero and was therefore dropped.

Our full (unadjusted) sample covers 59 developing countries representing about one-half of the total number of developing countries and nearly $90 \%$ of the total population living in developing countries. A quick glance at the list of countries reveals that these are more or less equally distributed across regions, thus ensuring the representativeness of the sample. Because the values for the variables racial $_{i}$ and gunn $2_{i}$ are not available for some countries, the full sample for the estimation of equations (10)-(11) is restricted to 50 countries.

The estimation results are given in Table 3a (for the human capital equation) and Table $3 \mathrm{~b}$ (for the growth equation). Table $3 \mathrm{a}$ provides the estimation results for the human capital equation. Column (1) reports the estimation results obtained with ethnic diversity as the only control variable. Column (2) reports the estimation results obtained after adding workers' remittances as a control variable. As apparent from Table 3a, workers' remittances turned out to be insignificant in the human capital equation, at least for the full sample. However, workers's remittances were found to be significant for the sub-samples. ${ }^{21}$

Table $3 a$ : Estimation results

Dependent variable=gross investment in human capital. Full Sample

\begin{tabular}{|c|c|c|c|c|}
\hline Variable & (1) & (2) & (3) & (4) \\
\hline \multirow[t]{2}{*}{$m$} & 0.052 & 0.049 & 0.052 & 0.051 \\
\hline & [6.93] & [7.09] & [6.11] & [9.73] \\
\hline \multirow[t]{2}{*}{ avelf } & -0.0064 & -0.0070 & -0.0089 & -0.008 \\
\hline & {$[-3.12]$} & {$[-2.81]$} & {$[-1.99]$} & {$[-3.49]$} \\
\hline \multirow[t]{2}{*}{ rem } & - & 0.054 & 0.072 & 0.030 \\
\hline & & [0.67] & [1.02] & [0.96] \\
\hline \multirow[t]{2}{*}{ highex } & - & - & 0.013 & - \\
\hline & & & {$[0.84]$} & \\
\hline$R^{2}$ & 0.728 & 0.729 & 0.779 & 0.782 \\
\hline$J$ test & 0.161 & 0.202 & 0.267 & - \\
\hline Nobs & 50 & 50 & 50 & 59 \\
\hline \multicolumn{5}{|l|}{ Notes } \\
\hline $\begin{array}{l}\text { a) Between } \\
\text { b) Columns } \\
\text { c) Instrume } \\
\text { d) Column } \\
\text { e) The J tes }\end{array}$ & $\begin{array}{l}\text { ite Correcti } \\
\text { ble estimati } \\
\text { ulation den }\end{array}$ & $\begin{array}{l}\text { dasticity. } \\
\text { ents used an } \\
\text { ns, stock of }\end{array}$ & D countries. & \\
\hline
\end{tabular}

Table 3a shows that the coefficient of the migration rate (the empirical counterpart of $\psi_{i}^{m}$ ) is highly significant and positive. Depending on the specification, the

\footnotetext{
${ }^{21}$ For the two sub-samples selected in Section 6 on the ground of data quality for migration rates, workers' remittances turned out to be significant at the $10 \%$ level.
} 
value of this coefficient lies between $4.9 \%$ and $5.2 \%$. It should be emphasized that this estimated value is rather stable across specifications (Columns 1 to 3 ) and estimation methods (instrumental variables or OLS). The values obtained for the $J$-test statistics related to the overidentification test strongly support in each specification the exogeneity assumption of the four instruments. In line with the findings of Easterly and Levine (1997), the effect of ethnic diversity on human capital formation is found to be negative and significant. Finally, the share of public expenditures in higher education was found to be positive but not significant (see Column 3); however, one should take the latter result with caution since the definitions of $H_{i}$ and highex $i$ are not fully consistent. ${ }^{22}$

Table $3 \mathrm{~b}$ reports the estimation results for the growth equation. This equation is estimated over the 1985-1995 period in a panel regression framework. Using panel data provides at least two main advantages compared to a pure cross-sectional analysis. First, pooling time-series data and cross-sectional data increases the number of observations. More importantly, panel analysis allows us to account for unobserved heterogeneity. Such an heterogeneity may play an important role in growth analysis (indeed, introducing individual effects in growth regressions tends to explain an important part of the variability in growth performances across countries). We consider two time-series observations: average growth between 1985 and 1990 on the one hand, and between 1990 and 1995 on the other hand. These observations are available for 50 countries. We build on earlier work by Easterly and Levine (1997) for choosing the basic specification. In particular, we account for possible catching-up effects à la Barro and Sala-I-Martin through the introduction of the (log of) initial income. We also introduce regional dummies for Sub-Saharan Africa and Latin America, which were found highly significant in the growth equations of Easterly and Levine (1997). Since we use time-invariant explanatory variables, the model is estimated with random individual effects.

\footnotetext{
${ }^{22}$ Note that the choice of IV estimation methods prevents the estimation of equation (10) with more than five explanatory variables.
} 
Table $3 b$ : Estimation results

Dependent variable $=$ growth of GDP per head (g). Full Sample

\begin{tabular}{lcccc}
\hline \hline Variable & $(1)$ & $(2)$ & $(3)$ & $(4)$ \\
\hline Log(hum) & 0.0204 & 0.0232 & 0.0232 & 0.0239 \\
& {$[2.01]$} & {$[2.25]$} & {$[2.24]$} & {$[2.31]$} \\
Log(initial income) & -0.0254 & -0.0255 & -0.0270 & -0.0278 \\
& {$[-2.02]$} & {$[-2.03]$} & {$[-2.15]$} & {$[-2.24]$} \\
Log(Phones) & 0.1463 & 0.1433 & 0.1431 & 0.1251 \\
& {$[1.80]$} & {$[1.77]$} & {$[1.89]$} & {$[1.71]$} \\
rem & & 0.3234 & & 0.4570 \\
& & {$[0.393]$} & & {$[0.683]$} \\
gunn2 & & - & & 0.0803 \\
& & & & {$[0.837]$} \\
assass & & & 0.0845 & -0.00002 \\
& & & {$[1.38]$} & {$[-0.303]$} \\
Sub-saharian & & -0.0118 & 0.0569 \\
& & & {$[-0.172]$} & {$[0.863]$} \\
Latin America & & 0.782 & 0.0085 \\
& 100 & 100 & 100 & {$[0.123]$} \\
\hline$R^{2}$ & & & 0.782 \\
Nobs & & & 100 \\
\hline \hline
\end{tabular}

Note : Panel Regression; Random individual effects ; time series observation : 1985-1990 and 1990-1995; 50 countries

The results show that an increase in the level of human capital tends to favor GDP growth. It is worth noting that this positive effect turns out to be very robust across various specifications. Depending on the specification, the impact of the proportion of the highly educated in the population (in logs) on the average growth rate of the GDP per capita ranges from 0.020 to 0.024 . This is consistent with the results obtained by Easterly and Levine (1997), who measured human capital through a country's general schooling attainment. Regardless of the specification, this positive growth effect of human capital is significant at the $5 \%$ level. This is also the case for the proxy variable for physical capital (phones $)_{i}$ ) at the $10 \%$ level. The results also support the presence of a convergence process over the period 1985-95 through the negative and significant effect of initial income. This convergence effect is also very robust across specifications. By contrast, the introduction of other control variables (such as political instability, ethnic diversity, or regional dummies) does not seem to increase the explanatory power of the growth regressions. Finally, it should be emphasized that, as expected, individual effects explain a significant part of the growth variability across countries: similar regressions that we carried out over the same sample in a pure cross-section framework turned out to give a $R^{2}$ value of about $30 \%$, whereas in 
our panel analysis, this value is close to $80 \% .^{23}$

\section{Country-specific results}

The estimation results obtained in the previous section may be used to compute the country-specific effects of the brain drain. Along the lines suggested in the theoretical model (Corollaries 1 to 3 ), we compare a country's current growth performance to its predicted performance under autarky (when setting the migration rate at zero), and sign the growth effect of a marginal increase in the migration probability of the highly educated both at the current level of migration and in the no-migration virtual case.

This allows us to address three distinct questions: i) Can a brain drain constitute a growth-enhancing opportunity?, ii) Should the brain drain be greater or smaller than its current level? and, iii) Who wins, who loses, and how much?

Our analysis in this section is restricted to the 30 countries that appear in Part A of Table 1, that is, for which the CD data are most reliable.

\subsection{Can a brain drain constitue a growth-enhancing oppor- tunity?}

May a sufficiently small brain drain stimulate growth in the source country? To address this question, we use Corollary 1 and compare the effect of a marginal increase in the migration probability $\left(\psi_{i}^{m}\right.$ evaluated at $\left.m_{i}=0\right)$ to the country-specific value of $\widetilde{H}_{i}\left(1-\widetilde{H}_{i}\right)$. Note that our linear specification of the human capital equation (10) implies that the marginal effect of the migration probability is constant and equals 0.052 (see column 1 in Table 3, part A). However, the predicted stock of human capital in the no-migration economy depends on country-specific variables and should, therefore, be computed for each country.

This is apparent from Figures 3.1 and 3.2, where the white areas measure the values of $\widetilde{H}_{i}\left(1-\widetilde{H}_{i}\right)$, renamed $B 0(i)$ in the legend, for each country. Countries for which the $B 0(i)$ bound is lower than the critical value 0.052 are those for which the brain drain may stimulate growth (as compared to the no-migration solution). The figures clearly show that for 14 countries (about $47 \%$ of the sub-sample but $85 \%$ of its total population), there is a clear interest in allowing (at least some of) the

\footnotetext{
${ }^{23}$ The cross-section regression results are available from the authors upon request.
} 
highly-educated citizens to emigrate. This is the case, in particular, for countries such as Indonesia, Ghana, China, Pakistan, Guyana, Jamaica or Trinidad-Tobago, which are all characterized by a very low proportion of highly educated within the population (formally, the value of hum is less than $2 \%$ in all of these countries). By contrast, countries for which the value of hum is above $5 \%$ (and which may therefore be described as having a relatively performant educational system), such as Ecuador, Korea, the Philippines, or Costa Rica, would benefit from a total ban on emigration.

\subsection{Should the brain drain be larger or smaller?}

To address this second question, we examine whether some countries may benefit from a marginal increase in the migration probability of their highly educated above its current level. Using Corollary 3, we determine whether $\psi_{i}^{m}\left(m_{i} ; \chi_{i}^{h} ; \epsilon_{i}^{h}\right)>\frac{H_{i}\left(1-H_{i}\right)}{1-m_{i}}$. Given our linear specification of the human capital equation, the critical value $\psi_{i}^{m}$ is the same as in the previous subsection (i.e., 0.052). For each country, the value for the bound $\frac{H_{i}\left(1-H_{i}\right)}{1-m_{i}}$, renamed $B 1(i)$ in the legend, is reported on Figures 3.1 and 3.2. It is apparent from these figures that a country would gain from increasing the magnitude of the brain drain when the bound $B 1(i)$ is below the critical value 0.052 . Using this criterion, the sample is divided between two distinct groups. Figure 3.1 gathers countries which would gain from an increase in migration probability of their highly educated, while Figure 3.2 gathers countries which would gain from a decrease in this probability.

Only 9 countries, less than one-third of the sample, are in the first group. However, this group includes the countries with the greatest demographic size (China, India, Indonesia, Brazil and Pakistan). By contrast, the second group comprises 21 countries of small and medium demographic size. These include the countries already mentioned in sub-section 5.1 as being potentially better-off under autarky (17 countries) and which combine a relatively performant educational system with relatively low migration rates. These also include 4 additional Carribbean or Central American countries (El Salvador, Guyana, Jamaica and Trinidad and Tobago), which combine a relatively poor educational system with extremely high migration rates $(26 \%, 77 \%$, $77.5 \%$ and $56 \%$ respectively). 
Figure 3.1 : Growth effect of a marginal increase in brain drain (countries with a positive effect evaluated at the current migration rate)

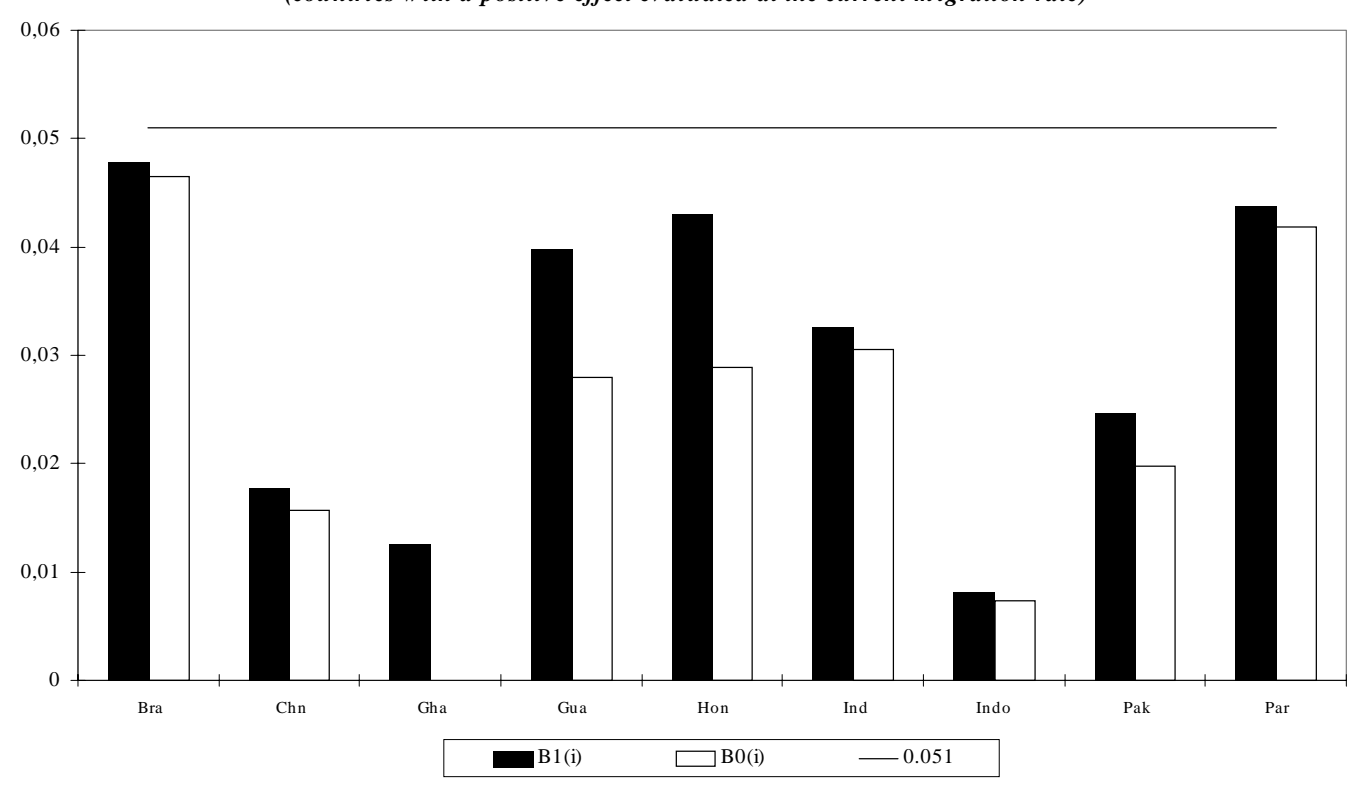

Figure 3.2 : Growth effect of a marginal increase in brain drain

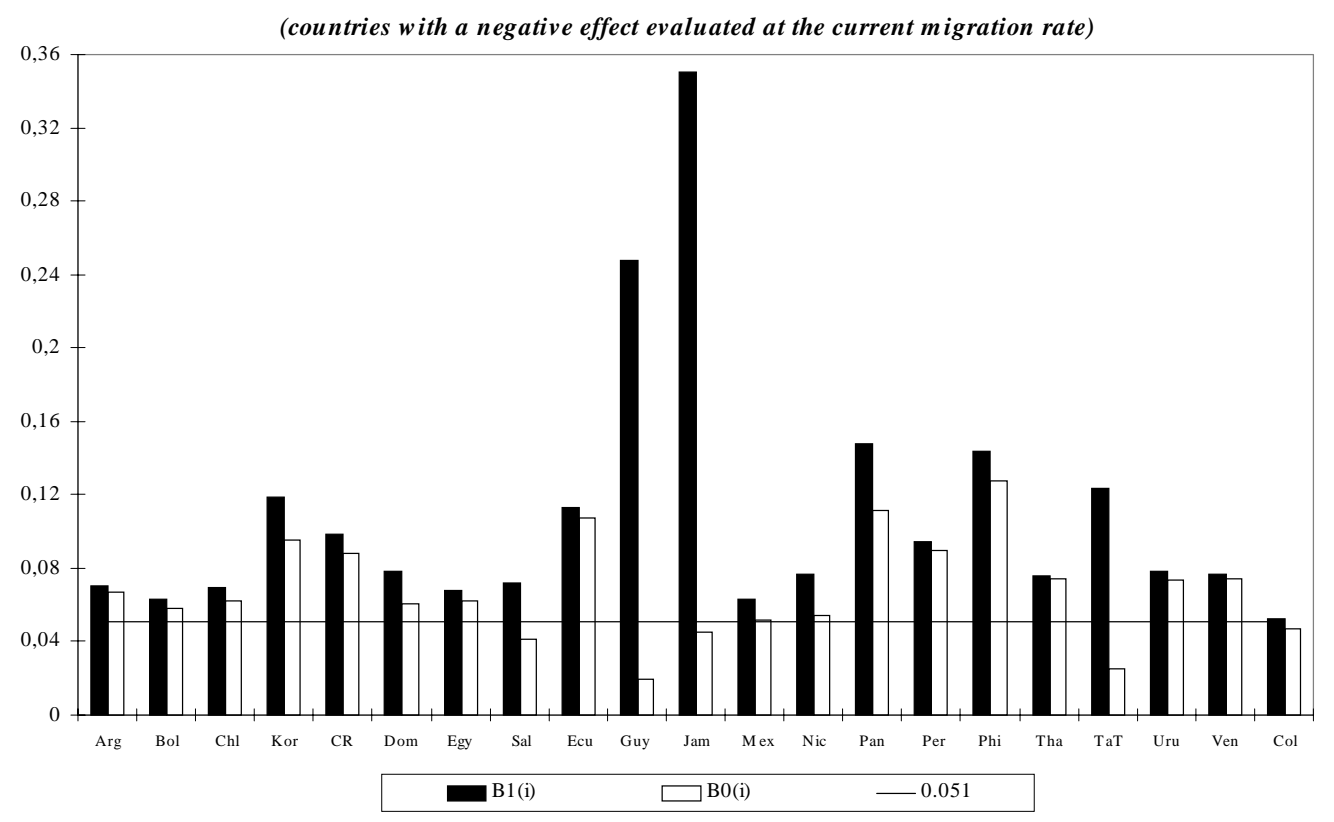


In conclusion, the set of countries for which an increase in the magnitude of brain drain would be growth-enhancing typically includes countries with low current migration rates (below 20\%) and low current levels of human capital (below 5\%). These conditions are verified in a limited number of cases but concern the biggest countries in terms of demographic size.

\subsection{Who loses, who wins, and how much?}

This third question may be dealt with using Corollary 2. Instead of computing the effect of a marginal increase in the brain drain, we now compute each country's predicted growth performance if the migration rate was set to zero, and compare it to its current (or observed) economic performance. Figure 4.1 reports the net positive gains of the winners and Figure 4.2 the net negative losses of the losers. Given the logarithmic specification used for equation (11), it is impossible to compute this effect for countries where $\widetilde{H}_{i}$ equals zero. Note also that, for countries which have very poor educational attainments, the procedure we use could lead to an overestimation of their gains. To avoid such cases, we exclude from our computations the countries for which either $\widetilde{H}_{i}=0$ or hum $_{i}<1 \%$.

Not surprisingly, countries that incur important losses are those which have very high migration rates. Nevertheless, it should be emphasized that the magnitude of the losses and gains, expressed in terms of annual growth rate of the GDP per capita, remains relatively limited for most countries. Notable exceptions are Jamaica and Guyana, which have extremely high migration rates. Except for these two countries, the net variation of the annual GDP per capita growth rate is always lower than $0.20 \%$ per year. This is certainly not negligible in a long-run perspective, but indicates that the growth effects of the brain drain have perhaps been overstated in previous research. 
Figure 4.1 : net growth gain (\% of annual GDP per head)

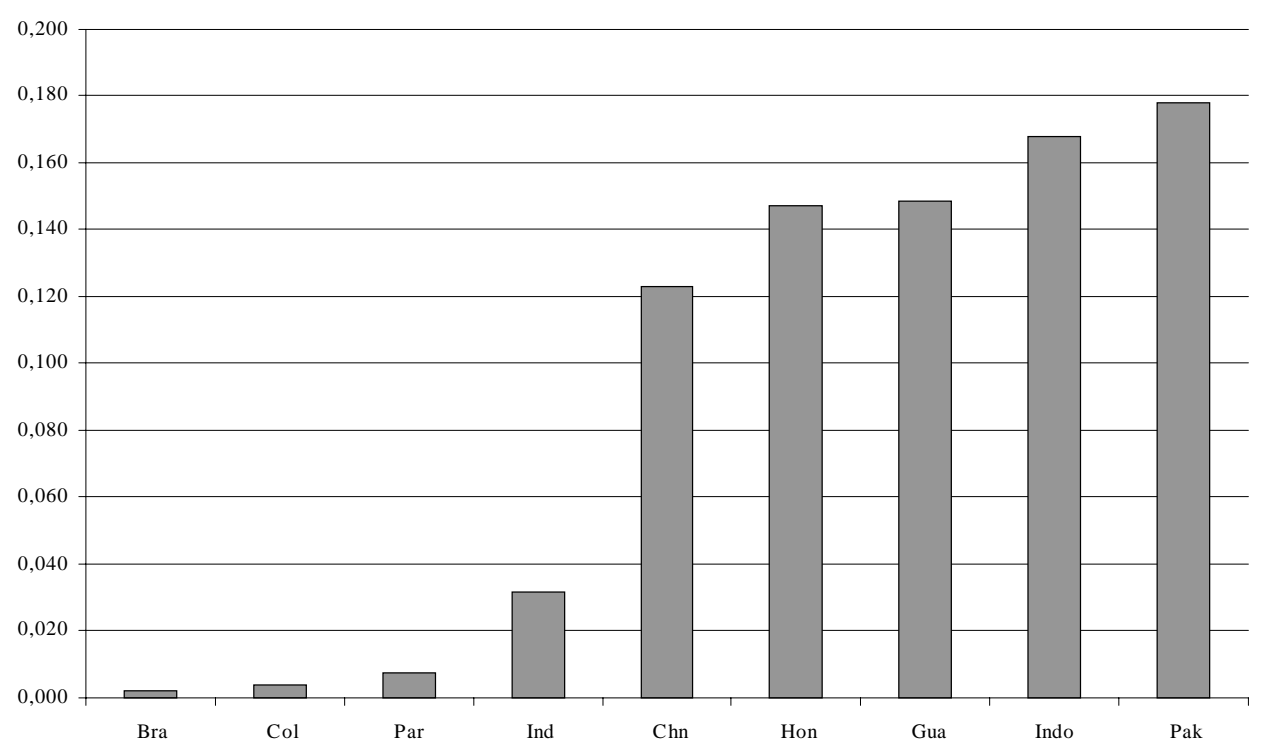

Figure 4.2 : growth net losses (\% of annual GDP per head)

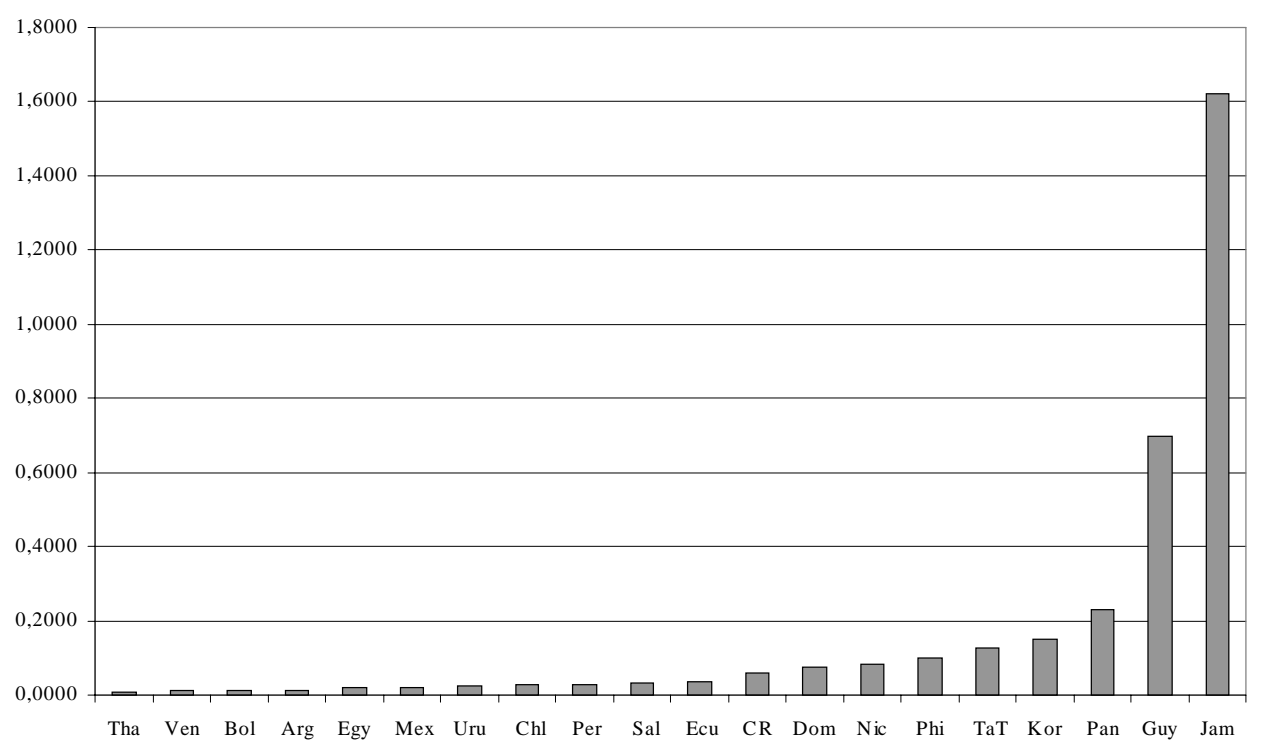

\section{Robustness analysis}

The computation of the net growth effects of the brain drain and the identification of losers and winners rests on the estimation of the derivative $\psi_{i}^{m}$, the coefficient of 
$m_{i}$ in the human capital equation. Since this estimate is so central to our analysis, we dedicate this section to a robustness analysis of the conclusions. Toward this end, we extend our econometric approach in two directions:

- We first consider three sub-samples of countries, selected on the grounds of the quality of the data on their migration rates.

- We then extend our basic specification for the human capital equation by allowing for non-linear growth effects of migration, as suggested in previous theoretical research.

\subsection{Selected samples}

Recall that the CD estimates were obtained by assuming that, for each country, the educational structure of its emigrants could be extrapolated from that observed for their immigrants to the US. The validity of this assumption is highly questionable for countries where the proportion of emigrants to the US is low, that is, for which the US is not the main emigration destination. To address this issue, we restrict our sample by dropping countries with poor data quality. We proceed in two steps.

First, we exclude from the sample the countries for which the data provided by CD is obviously misleading. As noticed by Carrington and Detragiache (1998, note $14 \mathrm{p}$. 20), "for a number of small countries, migratory flows to non-US OECD countries may be underestimated, because the reporting system of some receiving countries provides country-of-origin information for migrants from major sending countries [only]". As a result, a number of small countries appear in their data (see Part A of Table 1) with $100 \%$ of their immigrants to OECD countries choosing the US as destination. This is obviously erroneous and simply signals the lack of data on immigrants by country of origin in some non-US OECD countries. For Central and South American countries, however, a rate of $100 \%$ of immigrants to OECD countries choosing the US may approximate the reality ${ }^{24}$ while this is clearly not the case for small African countries (whose main destination is the EU) and, to a lesser extent, for countries from Asia and the Pacific, whose emigration destinations are relatively diversified.

\footnotetext{
${ }^{24}$ For example, Zlotnik (1998) notes that "the United States is the major destination of migrants from throughout Latin America and the Caribbean ... [while] the presence of Latin Americans in other regions remains limited" (p. 464).
} 
Applying this first rule gives a sub-sample of 38 countries, after the exclusion of Fiji, Papua New Guinea, Syria, and 18 out of 23 African countries (see Table 1).

Second, we exclude from the sample the countries for which the proportion of emigrants to the US is lower than a given threshold. We consider two possible thresholds: one-third, and one-half. ${ }^{25}$ Applying this second rule leads to the exclusion of $12(8+4)$ additional countries, giving sub-samples of 30 and finally 26 countries.

Table 4 presents the estimation results of equation (10) for these three subsamples, using a specification that includes ethnic diversity and workers' remittances, the latter variable being statistically significant in some of the subsamples. In addition, columns (4) through (6) report alternative results obtained for the same specification as in column (1), but with either a different value for the depreciation rate of human capital $d_{H}(15 \%$ instead of $10 \%$ ) (Columns 4 and 5 ) or using OLS estimations instead of IV estimations (Column 6).

Table 4 : Estimation results - Robustness analysis Dependent variable $=$ Gross investment in human capital. Adjusted samples

\begin{tabular}{ccccccc}
\hline \hline Variable & $(1)$ & $(2)$ & $(3)$ & $(4)$ & $(5)$ & $(6)$ \\
\hline$m$ & 0.056 & 0.052 & 0.047 & 0.055 & 0.056 & 0.060 \\
& {$[6.85]$} & {$[4.84]$} & {$[4.10]$} & {$[8.13]$} & {$[6.85]$} & {$[7.542]$} \\
avelf & -0.0082 & -0.0080 & -0.0044 & -0.0062 & -0.0083 & -0.012 \\
& {$[-1.723]$} & {$[-1.63]$} & {$[-0.69]$} & {$[-2.91]$} & {$[-1.72]$} & {$[-2.030]$} \\
rem & 0.105 & 0.167 & 0.202 & 0.105 & 0.105 & 0.032 \\
& {$[1.66]$} & {$[2.09]$} & {$[2.11]$} & {$[1.563]$} & {$[1.66]$} & {$[0.818]$} \\
\hline$R^{2}$ & 0.725 & 0.639 & 0.585 & 0.758 & 0.764 & 0.702 \\
J test & 0.303 & 0.516 & 0.754 & 0.276 & 0.303 & - \\
Nobs & 38 & 30 & 26 & 50 & 38 & 38 \\
\hline \hline Notes:
\end{tabular}

\section{Notes:}

a) Between brackets, T-statistics. White Corrections for heteroscedasticity.

b) Columns 1 to 4 Instrumental variable estimation, Four instuments and a constant

c) Instruments : population size, population density, racial tensions, stock of migrants in OECD.

d) Columns 4 and 5 : Depreciation rate of human capital set to $15 \%$ instead of $10 \%$.

e) Column $6:$ OLS estimation.

f) The $J$ test is an overidentification test.

On the whole, our conclusions regarding the impact of migration on human capital formation remain fairly similar when restricting the sample to ensure a higher quality of the migration data. Depending on the sub-sample and the specification used, the estimated coefficient of $\psi_{i}^{m}$ lies between $4.7 \%$ and $6.0 \%$, which is in line with the results obtained with the full sample (Table 3a). It is worth pointing out that when using the sub-samples, the positive effect of workers' remittances turns out to be

\footnotetext{
${ }^{25}$ This is in fact the "rule of thumb" proposed by Carrington and Detriagache (1998) to ensure the quality of their data.
} 
significant at a $10 \%$ level, whereas public expenditures on high education remain nonsignificant. Once more, for all specifications, the J-test of overidentification strongly supports the exogeneity assumption of the instruments.

\subsection{Allowing for non-linear effects}

Previous theoretical studies (Mountford, 1997, Beine et al., 2001) predicted nonlinear effects of migration prospects on human capital formation. More precisely, these models predicted that a net positive effect of the brain drain should be observed mostly in the poorest countries. The essence of the argument is that in such countries, the incentives to invest in human capital are extremely low unless substantial outside options are offered to prospective students. Using gross migration rates as a proxy for the brain drain, the empirical evidence documented in Beine et al. (2001) supported that prediction in a cross-section of 37 developing countries.

In this section, we test for such non-linear effects. To address this issue, we use the following specification for the human capital formation equation (10): ${ }^{26}$

$$
\Delta H_{i}+d_{H} H_{i, l a g}=b_{0}+b_{1} \cdot m_{i}+b_{2} \cdot\left(\text { dev }_{i} * m_{i}\right)+b_{3} . \text { avel } f_{i}+v_{i}
$$

where $d e v_{i}$ is a dummy variable which equals 1 if country $i$ is under a given threshold in terms of GDP per capita (see below) and 0 otherwise.

This specification involves a non-linearity in the variables; if additional effects are present for relatively less developed countries, the coefficient $b_{2}$ should be positive and significant. An important point concerns the choice of the threshold to be retained, and the underlying economic variable on which the threshold is based. We report the results obtained using the level of GDP per capita in $1990\left(g d p_{i}\right)$ as the underlying variable for which the threshold is defined, but very similar results were obtained using the level of education in $1990\left(\right.$ hum $\left._{i}\right)$ or the UNDP composite indicator of human development (Human Development Report, 1997). ${ }^{27}$ Given that, we end up with two endogeneous explanatory variables, leading to 2 degrees of freedom in the overidentification tests (instead of 3 previously). The identification tests lead to the same conclusions that the retained instruments may reasonably be considered as exogeneous.

\footnotetext{
${ }^{26}$ This specification is similar to that used by Beine et al. (2001).

${ }^{27}$ These results are not reported here but are available upon request.
} 
We first set the threshold value for the GDP per capita (in PPP value) at 1000 US\$, obtaining an almost perfect division of the full sample (24 countries out of 50 are below that threshold). Decreasing the value of the threshold to 600 US $\$$ leads to a sub-group of 18 poorest countries, and a further decrease to 400 US $\$$ gives a sub-group of only 11 countries. Table 5 reports the estimation results obtained for these different thresholds.

In contrast to Beine et al. (2001), Table 5 shows no evidence of non-linear effects of migration on human capital formation, whatever the threshold considered. In other words, the poorest countries do not seem to benefit from additional positive effects. For these countries indeed, the coefficient of $m_{i}$ remains significantly positive, and its value is quite similar to that reported in Table 3a. Rather, this stresses the robustness of the results to different specifications, thus confirming the previous results obtained with a linear specification.

Table 5 : Estimation results - Robustness analysis Dependent variable $=$ Gross investment in human capital. Nonlinear effects

\begin{tabular}{ccccc}
\hline \hline Variable/ Threshold & $g d p=1000$ & $g d p=800$ & $g d p=600$ & $g d p=400$ \\
\hline$m$ & 0.045 & 0.044 & 0.049 & 0.052 \\
& {$[4.40]$} & {$[3.60]$} & {$[6.03]$} & {$[6.73]$} \\
$d e v * m$ & 0.051 & 0.059 & 0.063 & 0.075 \\
& {$[0.71]$} & {$[0.66]$} & {$[0.77]$} & {$[0.66]$} \\
avelf & -0.010 & -0.010 & -0.010 & -0.010 \\
& {$[-1.56]$} & {$[-1.47]$} & {$[-1.75]$} & {$[-1.59]$} \\
\hline$R^{2}$ & 0.546 & 0.494 & 0.592 & 0.654 \\
J test & 0.112 & 0.128 & 0.089 & 0.112 \\
Nobs & 50 & 50 & 50 & 50 \\
\hline \hline
\end{tabular}

\section{Notes:}

a) between brackets, T-statistics; White Corrections for heteroscedasticity.

b) Columns 1 to 4 Instrumental variable estimation: four instuments and a constant.

c) Instruments : population size, population density, racial tensions, stock of migrants in OECD countries.

d) The $\mathbf{J}$ test is an overidentification test.

\section{Conclusion}

Our results provide empirical evidence supporting the "beneficial brain drain" hypothesis at an aggregate level. Using recent migration data by education levels computed by Carrington and Detragiache (1998), we showed that migration prospects exert a positive effect on human capital formation in a cross-section of 50 developing countries. This conclusion is robust to the choice of a variety of specifications used in our analysis: different control variables in the human capital equation, instrument 
variables to account for the endogeneity of the migration rate, quality of the measurement of these rates by education levels, and choice of a linear versus a non-linear specification to test for additional effects in the poorest countries.

A notable innovation of this paper is the computation of the growth effects of the brain drain for individual source countries. On the basis of our estimates, we identified the countries gaining or losing from the brain drain, comparing their respective gains and losses in terms of annual GDP growth. We found that most countries combining low levels of human capital and low emigration rates of their highly-educated are positively affected by the brain drain. By contrast, the brain drain appears to have negative growth effects in countries where the migration rate of the highly educated is higher than $20 \%$ and/or where the proportion of highly-educated in the total population is above $5 \%$. While there are more losers than winners, it is striking that the latter include the biggest countries in terms of demographic size, representing nearly $80 \%$ of the total population of the sample.

These results suggest that the traditional perception of the brain drain, often viewed as a kind of predation whereby rich countries extract the most valuable human resources from the poor countries, has no empirical justification at an aggregate level. The simple fact that, among sending countries, there are winners and losers, points to the necessity of a better understanding of the circumstances and factors favoring the occurence of a detrimental brain drain. Further empirical research is certainly required before policy implications may be derived for sending as well as receiving countries. From this perspective, we see two major possible extensions for this research. The first direction would is to better distinguish between the main potentially positive aspects of the brain drain. As underlined in the introduction, alongside the incentive to acquire education, on which we focused here, such positive channels include remittances, return migration of skilled professionals, and the creation of business networks. While we controlled for the impact of remittances, we were unable to control directly for the two other possible sources. Nevertheless, we have some reasons to believe that these other possible growth effects of the brain drain are small, at least for the period covered in our study. First, although there is no comparative data on return migration, there are many case-studies suggesting that reverse migration is negligible for the highly skilled unless it is preceeded by sustained economic growth. ${ }^{28}$ As to the creation of trade and business networks, it

\footnotetext{
${ }^{28}$ For example, Kwok and Leland (1982) indicate that only 6,000 out of the 50,000 college graduates
} 
is not clear how such networks affect human capital formation and, in addition, such positive aspects of globalization would seem to be more relevant for the 1990s than for the 1980s, which is the period covered in our study. A second possible extension of this research, therefore, would be to expand its time-horizon so as to test for possible dynamic effects in the relationship between migration and human capital formation.

\section{References}

Banks, A.S. (1994): Cross-National Time Series Data Archive, Center for Social Analysis, University of New York at Binghampton.

Barro, R. and J.W. Lee (1993): International Measures of Schooling Years and Schooling Quality, American Economic Review, Papers and Proceedings, 86, 2: 218-23.

Barro, R. and X. Sala-I-Martin (1995): Economic Growth, New-York: McGraw Hill.

Beck, T., A. Demirgüç-Kunt and R. Levine (1999): A New Database on financial Development and Structure, The World Bank, Mimeo.

Beine, M., F. Docquier and H. Rapoport (2001): Brain Drain and Economic Growth: Theory and Evidence, Journal of Development Economics, 64, 1: 275-89.

Bhagwati, J.N. and K. Hamada (1974): The brain drain, international integration of markets for professionals and unemployment, Journal of Development Economics, 1, 1: $19-42$.

Blomqvist, A.G. (1986): International migration of educated manpower and social rates of return to education in LDCs, International Economic Review, 27, 1: 165-74.

Broaded, C.M. (1993): China's response to the brain drain, Comparative Education Review, 37, 3: 277-303.

Carrington, W.J. and E. Detragiache (1998): How Big is the Brain Drain?, IMF Working Paper, No 98.

who left Taiwan during the period from 1960 to 1979 returned during that period. The experience of South Korea is also interesting. Despite the incentives offered to qualified returnees, less than $10 \%$ of Korean Ph.D. graduates from foreign universities returned home during the 1970s. Since the mid-1980s, this situation has changed and most Ph.D. graduates (about two-thirds) now tend to return, but it is clear that in the case of Korea economic growth precedeed rather than resulted from this reverse flow (Song, 1992). For China and India also, return flows appear marginal. We know that the Chinese authorities were extremely concerned by the absence of returns among their expatriate students in the late 1980s (see e.g. Broaded, 1993), whereas in India, even in the field IT - the recent development of which is often magnified as an example of industrial success -, it seems that the number of returning engineers is too small to have an impact (Saxenian, 2001, p. 26). 
Carrington, W.J. and E. Detragiache (1999): How extensive is the brain drain, Finance and Development, June: 46-49.

Carrington, W.J, E. Detragiache, and T. Vishwanath (1996): Migration with endogenous moving costs, American Economic Review, 86, 4: 909-30.

Domingues Dos Santos, M. and F. Postel-Vinay (2003): Migration as a source of growth: the perspective of a developing country, Journal of Population Economics, 16, 1: 161-75.

Easterly, W. and R. Levine (1997): Africa's Growth Tragedy: Policies and Ethnic Divisions, Quarterly Journal of Economics, 112, 4: 1203-50.

Easterly, W. and R. Levine (2001): What have we learned from a decade of empirical research on growth? It's not factor accumulation: stylized facts and growth models, World Bank Economic Review, 15: 177-219.

Funkhouser, E. (1995): Remittances from international migration: a comparison of El Salvador and Nicaragua, Review of Economics and Statistics, 77: 137-46.

Gaillard, J. and A.M. Gaillard (1997): The international migration of brains: exodus or circulation?, Science, Technology and Society, 2, 2.

Galor, O. and D. Tsiddon (1997): The distribution of human capital and economic growth, Journal of Economic Growth, 2, 1: 93-124.

Gastil, R.D. (1990): The Comparison Survey of Freedom: Experiences and Suggestions, Studies in Comparative International Development, XXV: 25-50.

Gould, D.M. (1994): Immigrant links to the home country: empirical implications for U.S. bilateral trade flows, The Review of Economics and Statistics, 76, 2: 302-16.

Grubel, H. G. and A. Scott (1966): The international flow of human capital, American Economic Review, 56: 268-74.

Hall, R.E. and C.I. Jones (1999): Why do some countries produce so much more output per worker than others?, Quarterly Journal of Economics, 114, 1: 83-116.

Hamada, K. (1977): Taxing the brain drain: A global point of view, in J. Bhagwati, ed.: The New International Order, Cambridge, Mass.: M.I.T. Press.

Haque, H.U. and A. Jahangir (1999): The quality of governance: second-generation civil reform in Africa, Journal of African Economies, 8: 65-106.

Haque, N.U and S.-J. Kim (1995): 'Human capital flight': impact of migration on income and growth, IMF Staff Papers, 42, 3: 577-607.

Johnson, H. (1967): Some economic aspects of the brain drain, Pakistan Development Review, 7, 3: 379-411.

Kwok, V. and H. Leland (1982): An economic model of the brain drain, American 
Economic Review, 72, 1: 91-100.

Lowell, L.B. (2000): H-1B temporary workers: estimating the population, Institute for the Study of International Migration, Georgetown University.

Lowell, L.B. and A.M. Findlay (2001): Migration of highly skilled persons from developing countries: impact and policy responses, Geneva: International Labour Office (Draft Synthesis Report).

Massey, D.S., L. Goldring and J. Durand (1994): Continuities in transnational migration: an analysis of nineteen Mexican communities, American Journal of Sociology, 99, 6: 1492-533.

McCormick, B. and J. Wahba (2000): Overseas unemployment and remittances to a dual economy, Economic Journal, 110: 509-34.

McCullock, R. and J.T. Yellen (1977): Factor mobility, regional development and the distribution of income, Journal of Political Economy, 85, 1: 79-96.

Miyagiwa, K. (1991): Scale economies in education and the brain drain problem, International Economic Review, 32, 3: 743-59.

Mountford, A. (1997): Can a brain drain be good for growth in the source economy?, Journal of Development Economics, 53, 2: 287-303.

Munshi, K. (2003): Networks in the modern economy: Mexican migrants in the US labor market, Quarterly Journal of Economics, 118, 2: 549-99.

OECD (2000): Trends in international migration, Paris: OECD Editions.

Ong, P.M., L. Cheng and L. Evans (1992): Migration of highly educated Asians and global dynamics, Asian and Pacific Migration Journal, 1, 3-4: 543-67.

Rapoport, H. and F. Docquier (2003): The economics of migrants' remittances, in L.-A. Gerard-Varet, S.C. Kolm and J. Mercier-Ythier, eds.: Handbook of the economics of giving, reciprocity and altruism, Amsterdam: North-Holland, forthcoming.

Rauch, J.E. and V. Trindade (2002): Ethnic chinese networks in international trade, Review of Economics and Statistics, 84, 1: 116-30.

Reichlin, G. and A. Rustichini (1998): Diverging patterns with endogenous labor migration, Journal of Economic Dynamics and Control, 22: 703-28.

Saxenian, A. (1999): Silicon Valley's new immigrant entrepreneurs, San Fransisco: Public Policy Institue of California.

Saxenian, A. (2001): Bangalore: The Silicon Valley of Asia?, CREDPR Working Paper No. 91, Stanford University.

Sivard, R. L. (1993): World Military and Social Expenditures, Washington D.C.: World 
Priorities, 15th edition.

Song, H. (1992): From brain drain to reverse brain drain: three decades of Korean experience, Science, Technology and Society, 2, 2: 317-45.

Summers, R. and A. Presston (1997): Penn-World Tables.

Stark, O., C. Helmenstein and A. Prskawetz (1997): A brain gain with a brain drain, Economics Letters, 55: 227-34.

Stark, O., C. Helmenstein. and A. Prskawetz (1998): Human capital depletion, human capital formation, and migration: a blessing or a 'curse'?, Economics Letters, 60, 3: 363-7.

United Nations (1997): Human Development Report, New York: UN Editions.

Todaro, M. (1996): Economic Development, Addison-Wesley, Sixth edition.

UNCTAD (1975): The reverse transfer of technology: Its dimensions, economic effects, and policy implications, United Nations Conference on Trade and Development.

Usher, D. (1977): Public property and the effects of migration upon other residents of the migrants'countries of origin and destination, Journal of Political Economy, 85, 5: 1001-20.

Vidal, J.-P. (1998): The effect of emigration on human capital formation, Journal of Population Economics, 11, 4: 589-600.

Wong, K.-Y. and C.K. Yip (1999): Education, economic growth, and brain drain, Journal of Economic Dynamics and Control, 23, 5-6: 699-726.

World Bank (2000): World Development Indicators, Washington: The World Bank.

Zlotnik, H. (1998): International migration 1965-96: An overview, Population and Development Review, 24, 3: 429-68. 


\section{IZA Discussion Papers}

\begin{tabular}{|c|c|c|c|c|}
\hline No. & Author(s) & Title & Area & Date \\
\hline 805 & $\begin{array}{l}\text { G. J. van den Berg } \\
\text { A. van Vuuren }\end{array}$ & The Effect of Search Frictions on Wages & 6 & $06 / 03$ \\
\hline 806 & G. J. van den Berg & $\begin{array}{l}\text { Multiple Equilibria and Minimum Wages in Labor } \\
\text { Markets with Informational Frictions and } \\
\text { Heterogeneous Production Technologies }\end{array}$ & 6 & $06 / 03$ \\
\hline 807 & $\begin{array}{l}\text { P. Frijters } \\
\text { M. A. Shields } \\
\text { N. Theodoropoulos } \\
\text { S. Wheatley Price }\end{array}$ & $\begin{array}{l}\text { Testing for Employee Discrimination Using } \\
\text { Matched Employer-Employee Data: } \\
\text { Theory and Evidence }\end{array}$ & 5 & $06 / 03$ \\
\hline 808 & $\begin{array}{l}\text { F. Docquier } \\
\text { H. Rapoport }\end{array}$ & $\begin{array}{l}\text { Remittances and Inequality: A Dynamic } \\
\text { Migration Model }\end{array}$ & 1 & $06 / 03$ \\
\hline 809 & $\begin{array}{l}\text { S. Commander } \\
\text { M. Kangasniemi } \\
\text { L. A. Winters }\end{array}$ & The Brain Drain: Curse or Boon? & 1 & $06 / 03$ \\
\hline 810 & $\begin{array}{l}\text { J. H. Abbring } \\
\text { G. J. van den Berg }\end{array}$ & $\begin{array}{l}\text { A Simple Procedure for the Evaluation of } \\
\text { Treatment Effects on Duration Variables }\end{array}$ & 6 & $06 / 03$ \\
\hline 811 & $\begin{array}{l}\text { M. Corak } \\
\text { W.-H. Chen }\end{array}$ & $\begin{array}{l}\text { Firms, Industries, and Unemployment Insurance: } \\
\text { An Analysis Using Employer-Employee Data }\end{array}$ & 1 & $06 / 03$ \\
\hline 812 & $\begin{array}{l}\text { J. T. Addison } \\
\text { T. Schank } \\
\text { C. Schnabel } \\
\text { J. Wagner }\end{array}$ & $\begin{array}{l}\text { German Works Councils in the Production } \\
\text { Process }\end{array}$ & 3 & $06 / 03$ \\
\hline 813 & E. P. Lazear & $\begin{array}{l}\text { Firm-Specific Human Capital: A Skill-Weights } \\
\text { Approach }\end{array}$ & 5 & $06 / 03$ \\
\hline 814 & $\begin{array}{l}\text { G. Ridder } \\
\text { G. J. van den Berg }\end{array}$ & $\begin{array}{l}\text { Measuring Labor Market Frictions: A Cross- } \\
\text { Country Comparison }\end{array}$ & 6 & $07 / 03$ \\
\hline 815 & $\begin{array}{l}\text { A. Aakvik } \\
\text { K. G. Salvanes } \\
\text { K. Vaage }\end{array}$ & $\begin{array}{l}\text { Measuring Heterogeneity in the Returns to } \\
\text { Education in Norway Using Educational Reforms }\end{array}$ & 6 & $07 / 03$ \\
\hline 816 & $\begin{array}{l}\text { T. T. Herbertsson } \\
\text { J. M. Orszag }\end{array}$ & $\begin{array}{l}\text { The Early Retirement Burden: Assessing the } \\
\text { Costs of the Continued Prevalence of Early } \\
\text { Retirement in OECD Countries }\end{array}$ & 3 & $07 / 03$ \\
\hline 817 & $\begin{array}{l}\text { T. M. Andersen } \\
\text { T. T. Herbertsson }\end{array}$ & Measuring Globalization & 2 & $07 / 03$ \\
\hline 818 & J. Pencavel & The Surprising Retreat of Union Britain & 3 & $07 / 03$ \\
\hline 819 & $\begin{array}{l}\text { M. Beine } \\
\text { F. Docquier } \\
\text { H. Rapoport }\end{array}$ & $\begin{array}{l}\text { Brain Drain and LDCs' Growth: Winners and } \\
\text { Losers }\end{array}$ & 1 & $07 / 03$ \\
\hline
\end{tabular}

An updated list of IZA Discussion Papers is available on the center's homepage www.iza.org. 